\title{
Geochemical caper fingerprints as a tool for geographical origin identification
}

\author{
Salvatore Pepi $\cdot$ Alessandro Sardella $\cdot$ Alessandra Bonazza $\cdot$ Carmela Vaccaro
}

Received: 27 September 2017 / Accepted: 22 December 2017

(C) Springer Science+Business Media B.V., part of Springer Nature 2018

\begin{abstract}
The identification of geographical origin of food products is important for both consumers and producers to ensure quality and avoid label falsifications. The caper plant (Capparis spinosa L., Brassicales Capparidaceae), a xerophytic shrub common in the Mediterranean area, produces buds and fruits that are commercialized in brine at high price. Those grown in Italy in the Aeolian Islands are renowned for their high quality. This study is aimed to establish a correlation between the geological and geochemical features of soil and the chemical composition of caper buds grown in two Aeolian Islands, Lipari and Salina. Major and trace elements were investigated by X-ray fluorescence and inductively coupled plasma-mass spectrometry in soil and caper samples from three localities in Lipari and Salina, and data from the three sites were compared by a nonparametric test, a correlation test and multivariate statistics (principal component analysis). The results allowed to
\end{abstract}

Electronic supplementary material The online version of this article (https://doi.org/10.1007/s10653-017-0063-y) contains supplementary material, which is available to authorized users.

S. Pepi $(\bowtie) \cdot$ C. Vaccaro

Department of Physics and Earth Sciences, University of Ferrara, via Saragat 1, 44121 Ferrara, Italy

e-mail: ppesvt@unife.it

A. Sardella $\cdot$ A. Bonazza $\cdot$ C. Vaccaro

Institute of Atmospheric Sciences and Climate ISAC-

CNR Bologna, via P. Gobetti 101, 40129 Bologna, Italy discriminate soils according to geolithological characteristics of each area and detect a statistically significant correspondence between soil and caper samples for the elements $\mathrm{Co}, \mathrm{Fe}, \mathrm{Mg}$ and $\mathrm{Rb}$, identifying thus possible geochemical caper fingerprints of origin. These results may also be useful to protect the high quality of Aeolian caper products by a suitable "Made in Italy" trademark and avoid falsifications and frauds.

Keywords Major and trace elements - Aeolian Islands · Soil · Principal component analysis · Traceability

\section{Introduction}

Scientific research for determination and authentication of geographical origin of food products has recently acquired relevance in investigations against frauds for consumer protection, due to scandals about falsifications that undermined consumer confidence and increased the attention for geographical origin of products (Ariyama et al. 2007; Di Giacomo et al. 2007; Swoboda et al. 2008; Bong et al. 2013; Longobardi et al. 2015; Ma et al. 2016; Pepi and Vaccaro 2017). In Europe, high-quality products are marked by specific designations: protected designations of origin (PDO) and protected geographical indications (PGI), following the rules by European Union Council Regulation 
(EEC) No. 2081/1992 and Regulation (EC) No. 178/2002 (Gonzálvez et al. 2000; De la Guardia and Gonzálvez 2013). The above specific designations refer to precise geographical areas, establishing an exclusive link between the place of production and all products coming from that area (Mantrov 2014). In order to protect the quality standards of food production certified by specific designations and prevent frauds, the European Union reinforced national control activities, encouraging scientific identification of markers of geographical origin that could ensure authenticity and geographical traceability.

Advances in methods and analytical techniques led to an increase in application of fingerprinting analysis of foods for identification of geographical origin (Gonzálvez et al. 2000; Bandoniene et al. 2013; De la Guardia and Gonzálvez 2013). Since in organic material the inorganic component is more stable than the organic one, several studies examined trace elements, suggesting the potential application for determination of geographical origin (Almeida and Vasconcelos 2003; Thiel et al. 2004; Fabiani et al. 2010; Furia et al. 2011; Zhao et al. 2011; Aceto et al. 2013; Versari et al. 2014). Other authors focused on geochemical characterization of food products associated with a specific geographical environment for prevention of fraudulent labelling (Nikkarinen and Mertanen 2004; Censi et al. 2014; Mercurio et al. 2014; Protano and Rossi 2014; Pepi et al. 2016, 2017a, b; Pii et al. 2017).

The studies on territoriality are based on the hypothesis that chemical elements detected in plants and in their products reflect those contained in the soil (Wilson 1998; Thiel et al. 2004; Van Leeuwen and Seguin 2006; Protano and Rossi 2014; D’Antone et al. 2017; Pepi et al. 2017b). Within these studies, the geographical features of the production area, such as the soil type and the climate, are considered relevant factors affecting the specific designations (Ariyama et al. 2007; Di Giacomo et al. 2007; Swoboda et al. 2008; Camargo et al. 2010; Lo Feudo et al. 2010; Adamo et al. 2012; Bong et al. 2013; Liu et al. 2014; Longobardi et al. 2015; Ma et al. 2016).

The "Made in Italy" trademark identifies food products of very high quality, due to the highly favourable climate and agronomic conditions of the Italian territory. Besides the standardized analyses routinely performed on these products, an accurate determination of geographical origin would be necessary to guarantee the quality and territoriality of the products "Made in Italy" and to unmask falsifications.

Capers and caper berries are among the most renowned Italian products in the world: these are, respectively, the edible flower buds and fruits of the caper plant, which species is commonly referred as Capparis spinosa L. (Brassicales Capparaceae) (Inocencio et al. 2002, 2005). The caper plant is a deciduous species with fleshy leaves and large white or pinkish flowers, requiring a semi-arid climate, high temperatures and strong winds. The young flower buds and the fruits are edible, and other parts of plants are used for the production of medicines, cosmetics and insecticides (Özcan 1999; Sozzi 2001; Rivera et al. 2003; Sozzi et al. 2012). The edible buds and fruits are usually commercialized in brine for food industry, at high price. About 10,000 tons are produced annually worldwide in 60 countries: in the Mediterranean areas, the main producers are Spain, Morocco, Turkey and the Italian islands of Pantelleria and the Aeolian Archipelago (Özcan 1999). The Aeolian Islands are known for the high quality of caper production due to favourable environmental conditions such as the Mediterranean climate, the volcanic soil and the exposure to wind and sea spray (Barbera and Di Lorenzo 1982), which define the territoriality of this product.

The purpose of our study was to establish a method to identify the geographical origin of caper buds grown in two of the Aeolian Islands, Lipari and Salina, by correlating geological features and geochemistry of soil with chemical composition of caper buds. A detailed and reliable geochemical characterization of capers from Aeolian Islands may also be useful to protect the high quality of this product by a "Made in Italy" trademark, in order to avoid possible falsifications and frauds.

\section{Materials and methods}

Geological setting and sampling areas

The Aeolian arc is an archipelago of active and dormant volcanoes in the Mediterranean area consisting of seven islands, Vulcano, Lipari, Salina, Alicudi, Filicudi, Panarea and Stromboli, with structural, volcanological and petrological variations. The main 
active volcanoes are restricted to the central islands (Lipari and Vulcano) and the eastern ones (Panarea and Stromboli): under these islands, the north-westward subduction of the Ionian lithospheric slab beneath the southern Tyrrhenian Sea causes an extensional stress regime and deep-focus earthquakes. The Tindari-Letojanni Fault, a first-order lithospheric fault, divides the western and eastern sectors of the Aeolian arc, separating the silica-rich magma compositions of central islands from the potassium-rich ones of western and eastern islands (Calanchi et al. 2002; Lucchi et al. 2013a). Our study focused on the islands of Lipari and Salina, located in the centre of Aeolian archipelago (Fig. 1). These islands formed between $267 \mathrm{ka}$ and 1400 A.D. through lava flows, scoriaceous deposits, lava domes and hydro-magmatic pyroclastic products (Forni et al. 2013; Lucchi et al. 2013a).

The studied areas in Lipari were Lami $\left(38^{\circ} 29^{\prime} 47.21^{\prime \prime} \mathrm{N}, \quad 1^{\circ} 57^{\prime} 15.84^{\prime \prime} \mathrm{E}\right)$ and Pianogreca $\left(38^{\circ} 27^{\prime} 57.31^{\prime \prime} \mathrm{N}, 1^{\circ} 56^{\prime} 12.55^{\prime \prime} \mathrm{E}\right)$ (Fig. 1a, b). The Lami area belongs to the Pomiciazzo Formation, characterized by large obsidian-rich coulee with welldeveloped flow foliation (Bigazzi et al. 2003; Forni et al. 2013), while the Pianogreca area belongs to the Pianoconte Formation, composed by lower (70-56 ka) and intermediate (56-27 ka) brown tuffs. The study area in Salina was Leni $\left(38^{\circ} 33^{\prime} 17.09^{\prime \prime} \mathrm{N}\right.$, $14^{\circ} 49^{\prime} 29.22^{\prime \prime} \mathrm{E}$ ) (Fig. 1c), belonging to recent continental sediment and characterized by colluvial deposits produced by erosion of Punta Fontanelle
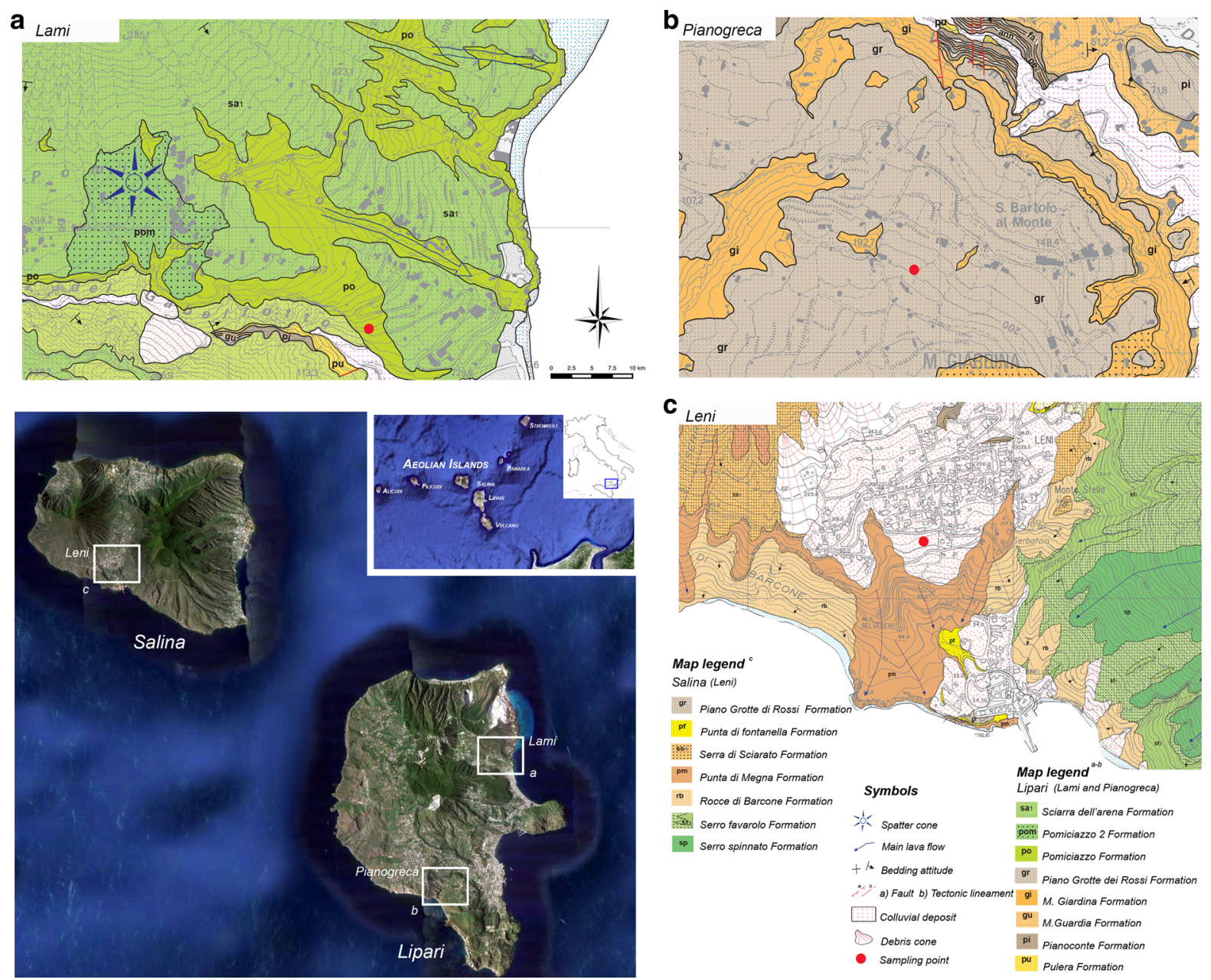

Fig. 1 Geological map of the Aeolian Islands, Italy (Lucchi et al. 2013a) showing the location of the three studied areas: "Lami" (a), "Pianogreca" (b), "Leni" (c) 
Formation, Pianoconte Formation and Serra di Sciarato Formation (Lucchi et al. 2013b).

Soil sampling was carried out in the three areas by an Edelman auger (Eijkelkamp Soil and Water, Giesbeek, The Netherlands). For each sampling area, ten caper plants in Pianogreca and 14 in Lami and Leni were chosen at random and soil samples were collected around the base of each caper plant at $50 \mathrm{~cm}$ of distance and $50 \mathrm{~cm}$ of depth. At harvest time, for each chosen plant in the three sampling areas, about 200 caper buds were randomly picked and stored in polyethylene bags at $4{ }^{\circ} \mathrm{C}$.

\section{Sample preparation and analysis}

The soil samples were prepared as pressed powder pellets for X-ray fluorescence (XRF) analysis. The samples were dried at $105{ }^{\circ} \mathrm{C}$ for $24 \mathrm{~h}$ to eliminate the hygroscopic water and ground in an agate mortar (Laarmann LMMG 100, Roermond, The Netherlands). An amount of about $3 \mathrm{~g}$ of powder, over a base of boric acid, was pressed by a hydraulic press to obtain pellets, which were analysed by a wavelengthdispersive spectrometer ARL ADVANT'XP (Thermo Fisher Scientific, Waltham, MA, USA). Simultaneously, $0.6 \mathrm{~g}$ portions of sample powder were heated for about $12 \mathrm{~h}$ in a muffle at $1000{ }^{\circ} \mathrm{C}$ for determining loss on ignition (LOI).

For inductively coupled plasma-mass spectrometry (ICP-MS), the soil samples were dried at $105{ }^{\circ} \mathrm{C}$ for $24 \mathrm{~h}$ and ground in the Laarman agate mortar. An amount of $0.20 \mathrm{~g}$ of powder was placed in a $50-\mathrm{mL}$ Teflon digestion vessel (Polytetrafluoroethylene), $43 \times 60 \mathrm{~mm}$ (VWR International, Milan, Italy), adding $3 \mathrm{~mL}$ of $\mathrm{HNO}_{3}$ (65\% in distilled water, Suprapur $^{\circledR}$, Merck KGaA, Darmstadt, Germany) and $6 \mathrm{~mL}$ of $\mathrm{HF}$ ( $40 \%$ in distilled water, Suprapur ${ }^{\circledR}$, Merck KGaA, Darmstadt, Germany). The mixture was heated on a hotplate at $180-190{ }^{\circ} \mathrm{C}$ for $4-5 \mathrm{~h}$ until complete drying. Afterwards, $3 \mathrm{~mL}$ of $\mathrm{NHO}_{3}$ and $3 \mathrm{~mL}$ of $\mathrm{HF}$ were added and the mixture was placed on hotplate for $3 \mathrm{~h}$. The dry residue was resuspended in $4 \mathrm{~mL}$ of $\mathrm{HNO}_{3}$ and placed on the hotplate until complete drying. The residue was finally resuspended in $2 \mathrm{~mL}$ of $\mathrm{HNO}_{3}$.

Caper samples were washed three times with highly purified Milli- ${ }^{\circledR}$ water (resistivity $18.2 \mathrm{M} \Omega \mathrm{cm}$ ) and then dried in an oven at $70^{\circ} \mathrm{C}$ for $24 \mathrm{~h}$. Once completely dried, the samples were ground in an herb grinder (MC3001-Moulinex, Italy). The ground samples were prepared for ICP-MS as follows: (1) $0.4 \mathrm{~g}$ portion of the sample was placed in a 50-mL Teflon digestion vessel, adding $4 \mathrm{~mL}$ of $\mathrm{HNO}_{3}(65 \%$ in distilled water, Suprapur ${ }^{\circledR}$, Merck KGaA, Darmstadt, Germany) and $3 \mathrm{~mL}$ of $\mathrm{H}_{2} \mathrm{O}_{2}$ (37\% in distilled water, Suprapur $^{\circledR}$, Merck); (2) the mixture was heated on a hotplate at $120-160{ }^{\circ} \mathrm{C}$ for $3 \mathrm{~h}$ until complete drying; (3) the dry residue was resuspended in $3 \mathrm{~mL}$ of $\mathrm{HNO}_{3}$ and $2 \mathrm{~mL}$ of $\mathrm{H}_{2} \mathrm{O}_{2}$ and placed on hotplate until complete drying. The dried samples were finally resuspended in $2 \mathrm{~mL}$ of $\mathrm{HNO}_{3}$.

The resultant solutions of all samples were transferred to plastic flasks and made up to $100 \mathrm{~mL}$ with highly purified Milli- $Q^{\circledR}$ water. An internal element standard composed of Rh, Re, In and Bi was added to each solution to obtain a final concentration of $10 \mathrm{ppb}$.

Analytical determinations

Major elements in soil samples were analysed by XRF, using a wavelength-dispersive spectrometer ARL ADVANT'XP (Thermo Fisher Scientific). The chemical composition of soils was expressed as a weight percentage of the following oxides: $\mathrm{SiO}_{2}, \mathrm{TiO}_{2}$, $\mathrm{Al}_{2} \mathrm{O}_{3}, \mathrm{Fe}_{2} \mathrm{O}_{3}, \mathrm{MnO}, \mathrm{MgO}, \mathrm{CaO}, \mathrm{Na}_{2} \mathrm{O}, \mathrm{K}_{2} \mathrm{O}, \mathrm{P}_{2} \mathrm{O}_{5}$. The accuracy and precision of data were evaluated using certified international soil standards (JSd-1 stream sediment powder, Geological Survey of Japan, Tsukuba, Japan). The analyses on international soil standards were replicated five times, and the detection limit (expressed in \% weight), the accuracy error and the precision (relative standard deviation, expressed in $\%)$ of the analyses are reported in Table 1.

The chemical elements in soil and caper samples were determined by ICP-MS using a Thermo Electron Corporation X series spectrometer (Thermo Fisher Scientific, Waltham, MA, USA). The elements determined were $\mathrm{Al}, \mathrm{B}, \mathrm{Ba}, \mathrm{Ca}, \mathrm{Cd}, \mathrm{Ce}, \mathrm{Co}, \mathrm{Cr}, \mathrm{Cu}, \mathrm{Dy}, \mathrm{Er}$, $\mathrm{Eu}, \mathrm{Fe}, \mathrm{Gd}, \mathrm{Ho}, \mathrm{K}, \mathrm{La}, \mathrm{Li}, \mathrm{Lu}, \mathrm{Mg}, \mathrm{Mn}, \mathrm{Mo}, \mathrm{Na}, \mathrm{Nb}$, $\mathrm{Nd}, \mathrm{Ni}, \mathrm{P}, \mathrm{Pb}, \mathrm{Pr}, \mathrm{Rb}, \mathrm{Sm}, \mathrm{Sr}, \mathrm{Tb}, \mathrm{Th}, \mathrm{Ti}, \mathrm{Tm}, \mathrm{U}, \mathrm{V}, \mathrm{Y}$, $\mathrm{Yb}, \mathrm{Zn}, \mathrm{Zr}$. The accuracy and precision of the ICP-MS analysis for soil samples were checked by certified international soil standard (SS-2 Contaminated soil, SCP science, Baie d'Urfé, Quebec, Canada) while for caper samples were checked by certified international plant standard (SRM 1547 Peach Leaves, National Institute of Standards and Technology, Gaithersburg, MD, USA). The detection limit was calculated as the 
Table 1 Detection limit, accuracy error and precision (relative standard deviation, RSD) of major elements in soil samples analysed by X-ray fluorescence (XRF)

\begin{tabular}{|c|c|c|c|}
\hline & Detection limit & Accuracy error & RSD \\
\hline $\mathrm{SiO}_{2}$ & 0.05 & 1.40 & 0.36 \\
\hline $\mathrm{TiO}_{2}$ & 0.01 & 4.41 & 4.24 \\
\hline $\mathrm{Al}_{2} \mathrm{O}_{3}$ & 0.05 & 6.65 & 0.72 \\
\hline $\mathrm{Fe}_{2} \mathrm{O}_{3}$ & 0.10 & 5.71 & 0.54 \\
\hline $\mathrm{MnO}$ & 0.05 & 2.09 & 4.86 \\
\hline $\mathrm{MgO}$ & 0.01 & 16.0 & 8.92 \\
\hline $\mathrm{CaO}$ & 0.04 & 2.93 & 0.66 \\
\hline $\mathrm{Na}_{2} \mathrm{O}$ & 0.01 & 3.81 & 3.82 \\
\hline $\mathrm{K}_{2} \mathrm{O}$ & 0.01 & 8.68 & 1.15 \\
\hline $\mathrm{P}_{2} \mathrm{O}_{5}$ & 0.01 & 12.6 & 17.6 \\
\hline
\end{tabular}

Detection limit is expressed in \% (w/w), and accuracy error and RSD are expressed in \%

concentration equivalent to three times the standard deviation on the background signal. The accuracy, precision and detection limit of the analysis for soil samples are reported in Table 2 and those of caper samples in Table 3.

Statistical analysis

The Kruskal-Wallis nonparametric test (with post hoc Dunn's test) was used to establish the differences among groups in all data, and Pearson's correlation test was used to evaluate the correlations in soil and caper samples. Principal component analysis (PCA) was chosen as multivariate analysis of all ICP-MS data of soil and caper samples, in order to reduce the dimensionality of the matrix and of the data set with minimal loss of information (Rencher 2002). All data analyses were carried out by the software XL STAT, version 2015.5.02 (Addinsoft, Paris, France).

\section{Results and discussion}

\section{Geochemical characterization of soil}

The data obtained by X-ray fluorescence (XRF) and inductively coupled plasma-mass spectrometry (ICPMS) on geochemical composition of soil samples collected from the three study areas are reported in Tables 4 and 5. The data concerning element concentrations in soil samples detected by XRF (Table 4) are
Table 2 Detection limit, accuracy error and precision (relative standard deviation, RSD) of major and trace elements in soil samples are analysed by inductively coupled plasma-mass spectrometry (ICP-MS)

\begin{tabular}{|c|c|c|c|}
\hline & Detection limit & Accuracy error & RSD \\
\hline $\mathrm{Al}$ & 1.5 & 5.6 & 8.6 \\
\hline $\mathrm{Ca}$ & 2.0 & 9.5 & 15 \\
\hline $\mathrm{Fe}$ & 1.5 & 16 & 13 \\
\hline $\mathrm{K}$ & 0.1 & 8.8 & 16 \\
\hline $\mathrm{Mg}$ & 0.1 & 5.9 & 11 \\
\hline $\mathrm{Na}$ & 0.1 & 4.4 & 13 \\
\hline $\mathrm{P}$ & 1.5 & 13 & 17 \\
\hline $\mathrm{Ti}$ & 1.0 & 5.4 & 8.4 \\
\hline $\mathrm{B}$ & 40 & 18 & 31 \\
\hline $\mathrm{Ba}$ & 12 & 10 & 9.1 \\
\hline $\mathrm{Cd}$ & 28 & 7.0 & 18 \\
\hline $\mathrm{Ce}$ & 0.5 & 2.9 & 3.4 \\
\hline Co & 2.5 & 3.2 & 8.9 \\
\hline $\mathrm{Cr}$ & 11 & 12 & 11 \\
\hline $\mathrm{Cu}$ & 33 & 13 & 4.6 \\
\hline Dy & 0.5 & 6.9 & 1.7 \\
\hline $\mathrm{Er}$ & 0.5 & 3.8 & 1.7 \\
\hline $\mathrm{Eu}$ & 0.5 & 2.4 & 10 \\
\hline $\mathrm{Gd}$ & 0.5 & 1.4 & 3.8 \\
\hline Ho & 0.5 & 3.0 & 3.3 \\
\hline $\mathrm{La}$ & 0.5 & 1.2 & 2.7 \\
\hline $\mathrm{Li}$ & 1.5 & 7.5 & 8.9 \\
\hline $\mathrm{Lu}$ & 0.5 & 0.4 & 5.1 \\
\hline $\mathrm{Mn}$ & 21 & 6.5 & 9.4 \\
\hline Mo & 1.5 & 15 & 6.7 \\
\hline $\mathrm{Nb}$ & 15 & 2.8 & 10 \\
\hline $\mathrm{Nd}$ & 0.5 & 2.9 & 1.5 \\
\hline $\mathrm{Ni}$ & 33 & 6.1 & 11 \\
\hline $\mathrm{Pb}$ & 10 & 15 & 5.5 \\
\hline $\operatorname{Pr}$ & 0.5 & 2.6 & 1.9 \\
\hline $\mathrm{Rb}$ & 1.5 & 1.5 & 1.6 \\
\hline $\mathrm{Sm}$ & 0.5 & 3.9 & 1.4 \\
\hline $\mathrm{Sr}$ & 7.0 & 1.0 & 5.8 \\
\hline $\mathrm{Tb}$ & 0.5 & 1.8 & 3.2 \\
\hline Th & 10 & 2.8 & 10 \\
\hline $\mathrm{Tm}$ & 0.5 & 7.1 & 4.7 \\
\hline $\mathrm{U}$ & 0.5 & 9.4 & 6.7 \\
\hline V & 26 & 7.7 & 17 \\
\hline $\mathrm{Y}$ & 0.5 & 1.8 & 4.6 \\
\hline $\mathrm{Yb}$ & 0.5 & 17 & 1.7 \\
\hline $\mathrm{Zn}$ & 33 & 20 & 7.3 \\
\hline
\end{tabular}


Table 2 continued

\begin{tabular}{llll}
\hline & Detection limit & Accuracy error & RSD \\
\hline $\mathrm{Zr}$ & 5.0 & 4.5 & 5.2 \\
\hline
\end{tabular}

Detection limit from $\mathrm{Al}$ to $\mathrm{Ti}$ is expressed in $\mathrm{mg} / \mathrm{kg}$ and from B to $\mathrm{Zr}$ in $\mu \mathrm{g} / \mathrm{kg}$. Accuracy error and RSD are expressed in $\%$

in agreement with those obtained by ICP-MS (Table 5) for the same samples. Statistically significant differences $(p<0.05)$ were obtained for major elements and trace elements in the soils of the different areas under study. The highest concentration value for oxides and for all soil samples was $\mathrm{SiO}_{2}$, followed by $\mathrm{Al}_{2} \mathrm{O}_{3}, \mathrm{Fe}_{2} \mathrm{O}_{3}, \mathrm{CaO}$ and $\mathrm{K}_{2} \mathrm{O}$. Examining the differences in oxide concentrations among sampling areas, $\mathrm{SiO}_{2}$ and $\mathrm{K}_{2} \mathrm{O}$ resulted much higher in Lami and Pianogreca in comparison with Leni, whereas $\mathrm{Al}_{2} \mathrm{O}_{3}$, $\mathrm{Fe}_{2} \mathrm{O}_{3}, \mathrm{CaO}$ were higher in Leni. Concerning trace elements, the highest concentration value for all samples was $\mathrm{Sr}$, followed by $\mathrm{Ba}, \mathrm{Rb}, \mathrm{V}, \mathrm{Zr}$ and $\mathrm{Cu}$. The highest concentrations of $\mathrm{Ba}$ and $\mathrm{Rb}$ were detected in Pianogreca, while the major amount of $\mathrm{Sr}$ was found in Leni.

The correlations among all elements in soil samples from Lami, Leni and Pianogreca were calculated by Pearson's correlation test (Appendix Table A.1 in Supplementary material). All elements in soil samples showed significant positive and negative correlations $(p<0.05)$, except $\mathrm{U}$ for Leni and $\mathrm{Pb}$ for Pianogreca. In detail, a significant positive correlation of $\mathrm{Mg}$ versus Ca was detected in Lami, Leni and Pianogreca, whereas a significant positive correlation of Fe versus $\mathrm{V}$ was detected only in Lami and Pianogreca (Appendix Table A.1 in Supplementary material). These data suggest different concentrations of these elements according to geographical origin of soils.

Total alkali silica (TAS) and $\mathrm{K}_{2} \mathrm{O}$ versus $\mathrm{SiO}_{2}$ diagrams are shown in Appendix Fig. A.1 in Supplementary material (Ewart 1982; Le Bas et al. 1986). According to TAS diagram, Lami samples belong to andesite and dacite fields, Leni samples to basaltic andesite and Pianogreca to dacite-trachydacite (Appendix Fig. A.1a in Supplementary material). The $\mathrm{K}_{2} \mathrm{O}$ versus $\mathrm{SiO}_{2}$ diagram shows a wide variability of $\mathrm{K}_{2} \mathrm{O}$ content (Appendix Fig. A.1b in Supplementary material). Sample soils from Lami and Pianogreca belong to high-K andesite-dacite (HKAD) field, while soils from Leni belong to high-K basaltic-andesite (HKBA) field. The different composition of soils
Table 3 Detection limit, accuracy error and precision (relative standard deviation, RSD) of major and trace elements in caper samples analysed by inductively coupled plasma-mass spectrometry (ICP-MS)

\begin{tabular}{|c|c|c|c|}
\hline & Detection limit & Accuracy error & RSD \\
\hline $\mathrm{Al}$ & 0.75 & 12 & 20 \\
\hline $\mathrm{Ca}$ & 1.00 & 0.3 & 13 \\
\hline $\mathrm{Fe}$ & 0.75 & 8.5 & 19 \\
\hline $\mathrm{K}$ & 0.05 & 3.4 & 14 \\
\hline $\mathrm{Mg}$ & 0.03 & 12 & 16 \\
\hline $\mathrm{Na}$ & 0.03 & 3.6 & 10 \\
\hline $\mathrm{P}$ & 0.75 & 1.6 & 12 \\
\hline $\mathrm{Ti}$ & 0.50 & 5.6 & 17 \\
\hline B & 20.2 & 15 & 12 \\
\hline $\mathrm{Ba}$ & 6.00 & 0.8 & 19 \\
\hline $\mathrm{Cd}$ & 1.43 & 11 & 11 \\
\hline $\mathrm{Ce}$ & 0.25 & 0.9 & 9.0 \\
\hline Co & 1.25 & 14 & 14 \\
\hline $\mathrm{Cr}$ & 5.50 & 13 & 19 \\
\hline $\mathrm{Cu}$ & 10.5 & 7.4 & 11 \\
\hline Dy & 0.25 & 7.8 & 4.0 \\
\hline Er & 0.06 & 5.6 & 5.2 \\
\hline $\mathrm{Eu}$ & 0.13 & 13 & 6.5 \\
\hline Gd & 0.25 & 4.0 & 12 \\
\hline Ho & 0.08 & 5.3 & 11 \\
\hline $\mathrm{La}$ & 0.25 & 8.1 & 11 \\
\hline $\mathrm{Li}$ & 0.75 & 5.8 & 17 \\
\hline $\mathrm{Mn}$ & 10.7 & 2.1 & 13 \\
\hline Mo & 0.75 & 14 & 16 \\
\hline $\mathrm{Nb}$ & 1.08 & 3.8 & 10 \\
\hline $\mathrm{Nd}$ & 0.25 & 0.5 & 3.8 \\
\hline $\mathrm{Ni}$ & 16.5 & 12 & 13 \\
\hline $\mathrm{Pb}$ & 5.25 & 13 & 5.5 \\
\hline $\operatorname{Pr}$ & 0.25 & 2.4 & 5.6 \\
\hline $\mathrm{Rb}$ & 0.75 & 10 & 13 \\
\hline $\mathrm{Sm}$ & 0.13 & 6.7 & 2.8 \\
\hline $\mathrm{Sr}$ & 3.50 & 3.7 & 12 \\
\hline $\mathrm{Tb}$ & 0.01 & 16 & 7.0 \\
\hline Th & 5.00 & 2.2 & 9.4 \\
\hline $\mathrm{U}$ & 0.10 & 13 & 19 \\
\hline $\mathrm{V}$ & 11.3 & 12 & 13 \\
\hline $\mathrm{Y}$ & 0.10 & 1.6 & 5.5 \\
\hline $\mathrm{Yb}$ & 0.10 & 7.1 & 4.4 \\
\hline $\mathrm{Zn}$ & 16.5 & 0.3 & 10 \\
\hline $\mathrm{Zr}$ & 1.25 & 3.5 & 15 \\
\hline
\end{tabular}

Detection limit from $\mathrm{Al}$ to $\mathrm{Ti}$ is expressed in $\mathrm{mg} / \mathrm{kg}$ and from $\mathrm{B}$ to $\mathrm{Zr}$ in $\mu \mathrm{g} / \mathrm{kg}$. Accuracy error and RSD are expressed in $\%$ 
Table 4 Median concentrations of major elements in soil samples of the three studied areas analysed by X-ray fluorescence (XRF)

\begin{tabular}{lllll}
\hline & Lami & Leni & Pianogreca & $p$ value \\
\hline $\mathrm{SiO}_{2}$ & $67.3 \pm 2.6$ & $55.0 \pm 0.3$ & $65.1 \pm 1.4$ & $* * *$ \\
$\mathrm{TiO}_{2}$ & $0.37 \pm 0.1$ & $0.76 \pm 0.0$ & $0.40 \pm 0.1$ & $* * *$ \\
$\mathrm{Al}_{2} \mathrm{O}_{3}$ & $14.3 \pm 0.6$ & $17.4 \pm 0.2$ & $15.0 \pm 0.3$ & $* * *$ \\
$\mathrm{Fe}_{2} \mathrm{O}_{3}$ & $5.07 \pm 1.0$ & $10.1 \pm 0.3$ & $5.59 \pm 0.7$ & $* * *$ \\
$\mathrm{MnO}$ & $0.12 \pm 0.0$ & $0.17 \pm 0.0$ & $0.12 \pm 0.0$ & $* * *$ \\
$\mathrm{MgO}$ & $1.16 \pm 0.6$ & $3.36 \pm 0.1$ & $1.02 \pm 0.3$ & $* * *$ \\
$\mathrm{CaO}$ & $4.03 \pm 1.0$ & $8.92 \pm 0.2$ & $2.63 \pm 0.4$ & $* * *$ \\
$\mathrm{Na}_{2} \mathrm{O}$ & $3.35 \pm 0.2$ & $2.33 \pm 0.1$ & $2.23 \pm 0.2$ & $* * *$ \\
$\mathrm{~K}_{2} \mathrm{O}$ & $4.10 \pm 0.5$ & $1.77 \pm 0.1$ & $4.55 \pm 0.2$ & $* * *$ \\
$\mathrm{P}_{2} \mathrm{O}_{5}$ & $0.17 \pm 0.0$ & $0.19 \pm 0.1$ & $0.20 \pm 0.0$ & $* *$ \\
\hline $\mathrm{A}$ & &
\end{tabular}

A nonparametric multiple test (Test di Kruskal-Wallis) was applied. Major elements are expressed in \% (w/w). Experimental values correspond to the median \pm standard deviation (SD)

ns not significant

$p$ values $* *<0.01 ; * * *<0.001$

supports their origin from andesite-dacite rocks in Lipari and basaltic andesite in Salina (Calanchi et al. 2002; Lanzo et al. 2010; Cicchino et al. 2011; Lucchi et al. 2013a).

Bivariate plots of abundance of major elements versus $\mathrm{SiO}_{2}$ (Fig. 2) were used to investigate the mineralogical assemblages in soil composition (Table 4). The Lami and Pianogreca samples showed a significant negative correlation with $\mathrm{SiO}_{2}$ of $\mathrm{TiO}_{2}$, $\mathrm{Al}_{2} \mathrm{O}_{3}, \mathrm{CaO}, \mathrm{Fe}_{2} \mathrm{O}_{3}$ and $\mathrm{MgO}$, and a significant positive correlation of $\mathrm{Na}_{2} \mathrm{O}$. The same samples showed a significant negative correlation with $\mathrm{CaO}$ of $\mathrm{Na}_{2} \mathrm{O}$ and $\mathrm{K}_{2} \mathrm{O}$. The Leni samples showed a significant negative correlation of $\mathrm{Al}_{2} \mathrm{O}_{3}$ with $\mathrm{SiO}_{2}$, and a significant negative correlation with $\mathrm{CaO}$ of $\mathrm{Na}_{2} \mathrm{O}$ and $\mathrm{K}_{2} \mathrm{O}$ (Fig. 2). The negative correlation of $\mathrm{TiO}_{2}, \mathrm{Al}_{2} \mathrm{O}_{3}, \mathrm{Fe}_{2} \mathrm{O}_{3}$ and $\mathrm{MgO}$ versus $\mathrm{SiO}_{2}$ in Lami and Pianogreca samples had a well-defined regression line (Fig. 2a-d), suggesting the presence of mafic minerals (orthopyroxene, pyroxene and hornblende), clay minerals and/or hydroxides (Calanchi et al. 2002; Lucchi et al. 2013a, b). In the same samples, the well-defined regression lines of $\mathrm{CaO}$ and $\mathrm{Na}_{2} \mathrm{O}$ versus $\mathrm{SiO}_{2}$ and the high concentration of $\mathrm{CaO}$ in Leni (Fig. 2e, f) suggest the presence of sialic minerals ( $\mathrm{Na}$ and Ca plagioclase) and clay minerals (Cicchino et al. 2011; Lucchi et al. 2013a)
Table 5 Median concentrations of major and trace elements in soil samples of the three studied areas analysed by inductively coupled plasma-mass spectrometry (ICP-MS)

\begin{tabular}{|c|c|c|c|c|}
\hline & Lami & Leni & Pianogreca & $p$ value \\
\hline $\mathrm{Al}$ & $6.32 \pm 1.33$ & $7.39 \pm 0.94$ & $5.51 \pm 0.80$ & $* *$ \\
\hline $\mathrm{Ca}$ & $2.41 \pm 0.59$ & $3.95 \pm 0.61$ & $1.94 \pm 0.27$ & $* * *$ \\
\hline $\mathrm{Fe}$ & $3.45 \pm 0.74$ & $6.12 \pm 0.63$ & $3.36 \pm 0.37$ & $* * *$ \\
\hline $\mathrm{K}$ & $2.44 \pm 0.74$ & $0.96 \pm 0.08$ & $3.08 \pm 0.20$ & $* * *$ \\
\hline $\mathrm{Mg}$ & $0.61 \pm 0.17$ & $0.86 \pm 0.06$ & $0.61 \pm 0.08$ & $* * *$ \\
\hline $\mathrm{Na}$ & $1.51 \pm 0.41$ & $0.90 \pm 0.04$ & $1.19 \pm 0.13$ & $* * *$ \\
\hline $\mathrm{P}$ & $0.05 \pm 0.01$ & $0.09 \pm 0.02$ & $0.08 \pm 0.01$ & $* * *$ \\
\hline $\mathrm{Ti}$ & $0.21 \pm 0.05$ & $0.40 \pm 0.04$ & $0.24 \pm 0.03$ & $* * *$ \\
\hline $\mathrm{Mn}$ & $0.08 \pm 0.01$ & $0.12 \pm 0.01$ & $0.08 \pm 0.01$ & $* * *$ \\
\hline B & $106 \pm 31$ & $19.8 \pm 1.9$ & $109 \pm 10$ & $* * *$ \\
\hline $\mathrm{Ba}$ & $291 \pm 63$ & $437 \pm 64$ & $489 \pm 66$ & $* * *$ \\
\hline $\mathrm{Cd}$ & $4.03 \pm 1.04$ & $2.43 \pm 0.45$ & $5.66 \pm 0.21$ & $* * *$ \\
\hline $\mathrm{Ce}$ & $60.3 \pm 15.4$ & $39.4 \pm 8.7$ & $111 \pm 8.0$ & $* * *$ \\
\hline Co & $14.3 \pm 2.06$ & $26.6 \pm 2.2$ & $16.7 \pm 2.5$ & $* * *$ \\
\hline $\mathrm{Cr}$ & $20.2 \pm 4.0$ & $19.8 \pm 2.7$ & $38.9 \pm 8.9$ & $* * *$ \\
\hline $\mathrm{Cu}$ & $63.6 \pm 18$ & $135 \pm 15$ & $101 \pm 16$ & $* * *$ \\
\hline Dy & $3.41 \pm 0.91$ & $2.72 \pm 0.55$ & $4.71 \pm 0.35$ & $* * *$ \\
\hline $\mathrm{Er}$ & $2.14 \pm 0.58$ & $1.57 \pm 0.33$ & $2.78 \pm 0.21$ & $* * *$ \\
\hline $\mathrm{Eu}$ & $0.60 \pm 0.12$ & $1.06 \pm 0.19$ & $1.08 \pm 0.19$ & $* * *$ \\
\hline Gd & $4.13 \pm 1.12$ & $3.54 \pm 0.73$ & $7.02 \pm 0.56$ & $* * *$ \\
\hline Ho & $0.75 \pm 0.20$ & $0.58 \pm 0.12$ & $0.98 \pm 0.07$ & $* * *$ \\
\hline $\mathrm{La}$ & $27.6 \pm 9.1$ & $21.9 \pm 5.8$ & $69.1 \pm 6.8$ & $* * *$ \\
\hline $\mathrm{Li}$ & $45.1 \pm 12.2$ & $8.04 \pm 1.00$ & $44.8 \pm 3.9$ & $* * *$ \\
\hline $\mathrm{Lu}$ & $0.37 \pm 0.11$ & $0.24 \pm 0.06$ & $0.44 \pm 0.04$ & $* * *$ \\
\hline Mo & $3.82 \pm 1.13$ & $1.33 \pm 0.14$ & $4.36 \pm 0.41$ & $* * *$ \\
\hline $\mathrm{Nb}$ & $23.1 \pm 6.6$ & $8.58 \pm 3.75$ & $18.1 \pm 1.8$ & $* * *$ \\
\hline $\mathrm{Nd}$ & $22.3 \pm 6.4$ & $18.5 \pm 4.2$ & $42.4 \pm 4.0$ & $* * *$ \\
\hline $\mathrm{Ni}$ & $14.7 \pm 2.1$ & $19.0 \pm 2.1$ & $11.8 \pm 1.8$ & $* * *$ \\
\hline $\mathrm{Pb}$ & $20.3 \pm 4.0$ & $26.9 \pm 2.9$ & $29.3 \pm 3.2$ & $* * *$ \\
\hline $\operatorname{Pr}$ & $6.17 \pm 1.9$ & $4.50 \pm 1.09$ & $11.9 \pm 1.1$ & $* * *$ \\
\hline $\mathrm{Rb}$ & $151 \pm 44$ & $29.0 \pm 5.7$ & $166 \pm 15$ & $* * *$ \\
\hline $\mathrm{Sm}$ & $4.48 \pm 1.14$ & $3.79 \pm 0.80$ & $7.52 \pm 0.63$ & $* * *$ \\
\hline $\mathrm{Sr}$ & $333 \pm 107$ & $670 \pm 61$ & $560 \pm 112$ & $* * *$ \\
\hline $\mathrm{Tb}$ & $0.67 \pm 0.17$ & $0.55 \pm 0.11$ & $0.99 \pm 0.08$ & $* * *$ \\
\hline Th & $23.7 \pm 8.4$ & $5.59 \pm 3.89$ & $49.8 \pm 4.1$ & $*$ \\
\hline $\mathrm{Tm}$ & $0.39 \pm 0.11$ & $0.26 \pm 0.06$ & $0.47 \pm 0.04$ & $* * *$ \\
\hline $\mathrm{U}$ & $10.4 \pm 1.6$ & $7.16 \pm 0.92$ & $9.84 \pm 1.13$ & $* *$ \\
\hline V & $164 \pm 44$ & $296 \pm 46$ & $121 \pm 17$ & $* * *$ \\
\hline Y & $18.2 \pm 7.9$ & $14.1 \pm 3.7$ & $31.6 \pm 3.6$ & $* * *$ \\
\hline $\mathrm{Yb}$ & $2.36 \pm 0.67$ & $1.56 \pm 0.35$ & $2.84 \pm 0.24$ & $* * *$ \\
\hline $\mathrm{Zn}$ & $70.5 \pm 12.4$ & $108 \pm 5.6$ & $77.3 \pm 7.0$ & $* * *$ \\
\hline
\end{tabular}


Table 5 continued

\begin{tabular}{lllll}
\hline & Lami & Leni & Pianogreca & $p$ value \\
\hline $\mathrm{Zr}$ & $165 \pm 36$ & $102 \pm 20$ & $146 \pm 11$ & $* * *$ \\
\hline
\end{tabular}

A nonparametric multiple test (Test di Kruskal-Wallis) was applied. Major elements from $\mathrm{Al}$ to $\mathrm{Mn}$ are expressed in \% (w/ $\mathrm{w}$ ), and trace elements from $\mathrm{B}$ to $\mathrm{Zr}$ are expressed in $\mathrm{mg} / \mathrm{kg}$. Experimental values correspond to the median \pm standard deviation (SD)

$n s$ not significant

$p$ values $* *<0.01 ; * * *<0.001$

The scatter plots of $\mathrm{Na}_{2} \mathrm{O}$ and $\mathrm{K}_{2} \mathrm{O}$ versus $\mathrm{CaO}$ (Fig. 2g, h) showed significant negative correlations for Lami and Pianogreca samples. A significant positive correlation of $\mathrm{Na}_{2} \mathrm{O}$ versus $\mathrm{CaO}$ was detected for Leni (Fig. 2g) but no significant correlation was observed for the same samples in scatter plot of $\mathrm{K}_{2} \mathrm{O}$ versus $\mathrm{CaO}$ (Fig. 2h). These results suggest the presence of calcium and sodium plagioclase in soils of Leni samples.

The scatter plots of $\mathrm{Ca}$ and $\mathrm{Eu}$ versus $\mathrm{Mg}$, of $\mathrm{Co}$ versus $\mathrm{Fe}$ and $\mathrm{Zr}$ versus $\mathrm{Nb}$ for all soil samples (Table 5) are shown in Fig. 3. Significant positive correlations were detected for all soil samples in all scatter plots, except for Eu versus $\mathrm{Mg}$ (Fig. 3b). However, within these significant positive correlations, a clear separation due to different geochemical and mineralogical composition is evident in Lami and Pianogreca samples, from Lipari Island, and those of Leni, from Salina Island (Fig. 3a, c, d). The same separation is also evident in the scatter plot of $\mathrm{Eu}$ versus $\mathrm{Mg}$ (Fig. 3b), where no significant correlation was detected.

Overall, the data suggest that the variations of element composition in the investigated soils are essentially dependent on geochemical processes occurring in the two islands.

Rare earth elements distribution in soil and caper samples

Chemical composition of rare earth elements (REE) in soil and caper samples collected from each area is, respectively, reported in Tables 5 and 6. Statistically significant differences $(p<0.05)$ in soil samples were obtained for all elements and study areas (Table 5). The highest REE values in soil were in Pianogreca, followed by Lami and Leni, respectively. Correlations among REE were calculated for soil samples in all study areas: all showed significant positive correlations $(p<0.05)$, except $\mathrm{Eu}$ for Lami (Appendix Table A.1 in Supplementary material). The REE concentrations in soil samples were normalized according to chondrite concentrations (McDonough and Sun 1995), and the distribution patterns are reported in Fig. 4a. These patterns were characterized by a progressive decrease in chondrite-normalized REE concentrations along the series and by negative anomalies of Eu in Pianogreca and Lami (Fig. 4a). The mobility of REE in soil is linked to chemical availability, organic matter, $\mathrm{pH}$, fertilizers, redox potential conditions and texture (Kabata-Pendias 2011; Aide and Aide 2012; Pepi et al. 2016). The $\mathrm{Eu}$ negative anomalies in soil (Fig. 4a) are probably linked to fractionation of plagioclase when $\mathrm{Ca}$ replaces Eu (Censi et al. 2014; Pepi et al. 2016): the $\mathrm{Eu}$ anomaly allows to identify the petrogenetic processes of Lami and Pianogreca in Lipari in comparison with those of Leni in Salina.

Concerning REE distribution in caper samples, the highest values were found in Leni, followed by Lami and Pianogreca, respectively (Table 6). The correlations among REE for caper samples were calculated in the investigated areas of the present study. All REE values were significantly different, either positively or negatively $(p<0.05)$, except Ce and Pr in Lami and La in Leni (Appendix Table A.2 in Supplementary material). The REE concentrations in caper samples were normalized according to chondrite concentrations (McDonough and Sun 1995), and the distribution patterns are reported in Fig. 4b. In this case, the REE patterns were characterized by a progressive decrease in chondrite-normalized concentrations along the series, together with Eu positive anomalies and $\mathrm{Sm}$ and Gd negative anomalies in both Lami and Pianogreca (Fig. 4b). As in soil samples, the Eu positive anomaly may be related to the physiological ability of this rare element to replace $\mathrm{Ca}^{2+}$ in aerial parts of the plant (Zeng et al. 2003), binding to proteins in a stronger way in comparison with $\mathrm{Ca}^{2+}$ (Kruk et al. 2003). The Gd and Sm negative anomalies suggest an environmental pollution due to an anthropogenic contamination of water used for irrigation (Brioschi et al. 2013; Merschel et al. 2015). Overall, these REE anomalies in caper samples apparently reflect those of the respective growth areas. In Leni, lower REE concentrations were found in soil than in caper 
Fig. 2 Bivariate plots of abundances of $\mathrm{SiO}_{2}$ versus $\mathrm{TiO}_{2}$ (a), $\mathrm{Al}_{2} \mathrm{O}_{3}$ (b) $\mathrm{Fe}_{2} \mathrm{O}_{3}$, (c), $\mathrm{MgO}$ (d) $\mathrm{CaO}$ (e) $\mathrm{Na}_{2} \mathrm{O}$ (f) and of $\mathrm{CaO}$ versus $\mathrm{Na}_{2} \mathrm{O}$ (g) and $\mathrm{K}_{2} \mathrm{O}(\mathbf{h})$, in soil samples from Lami, Leni and Pianogreca. Values of oxides are expressed in \% (w/w)
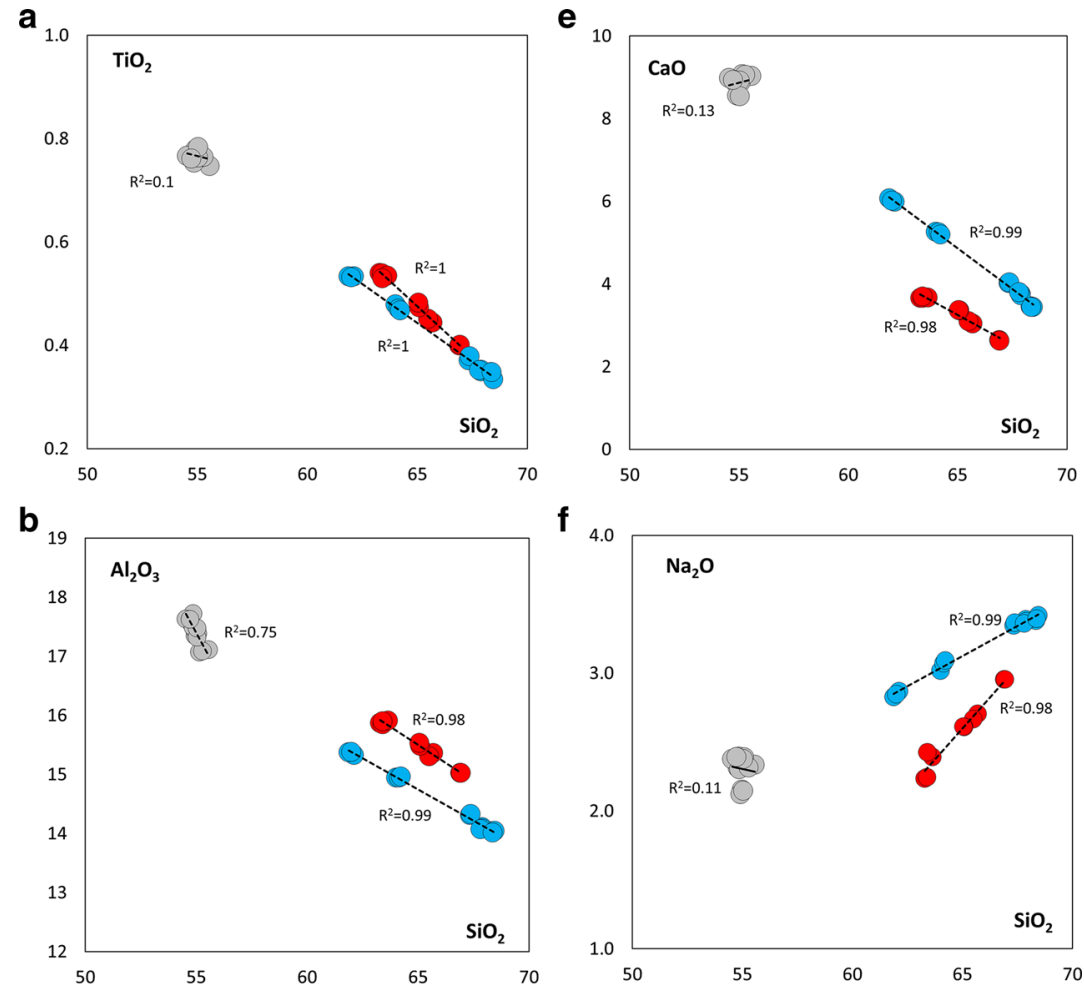

C
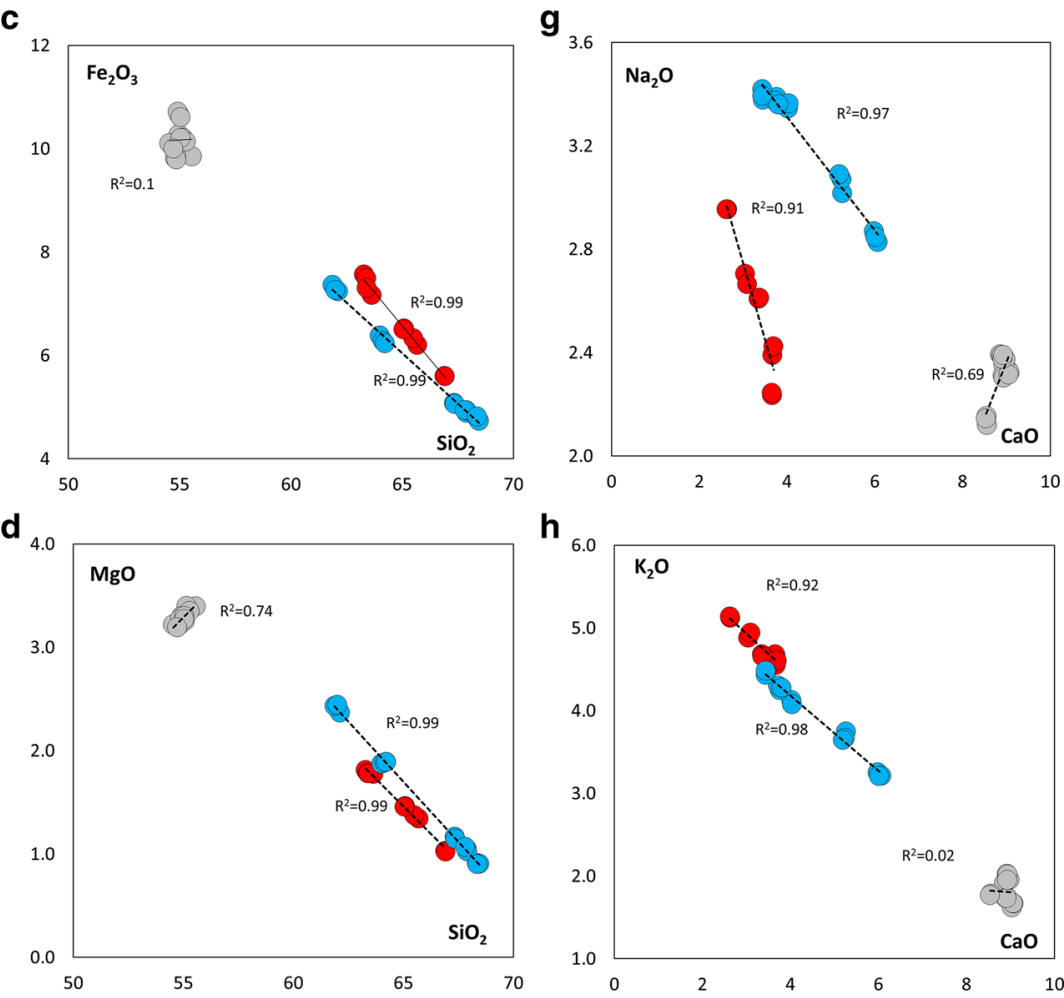

h

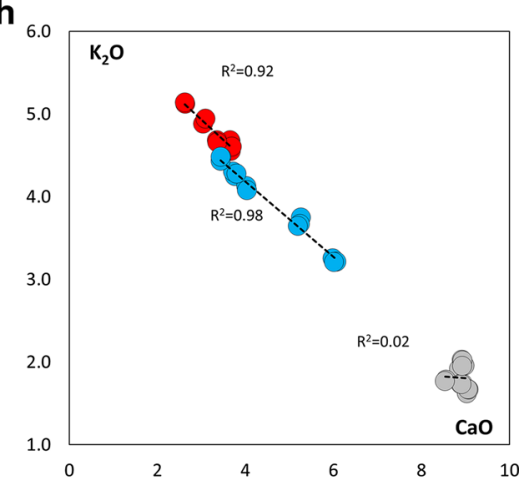

- Lami Leni Pianogreca 

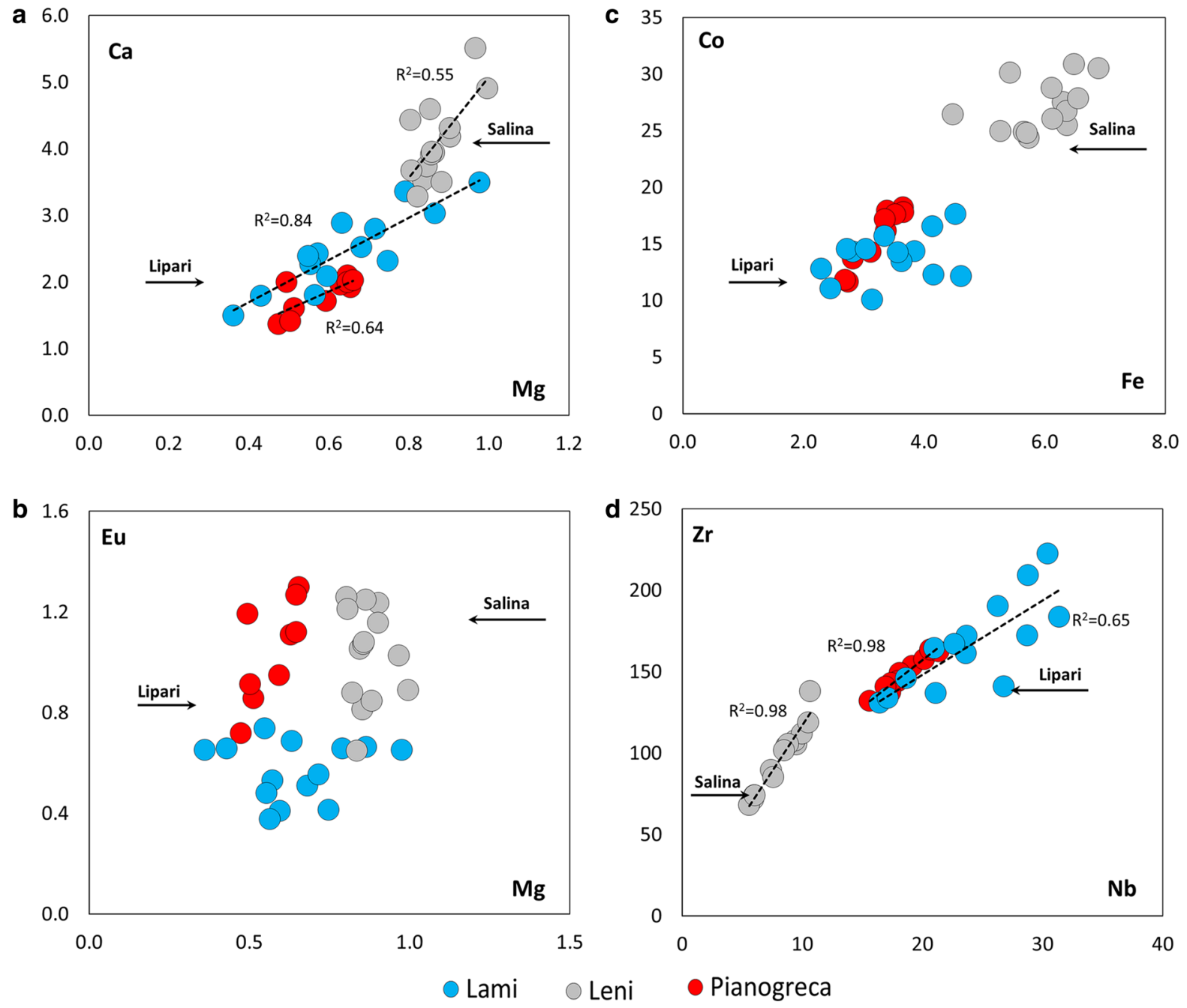

Fig. 3 Bivariate plots of major and trace elements of $\mathrm{Mg}$ versus $\mathrm{Ca}(\mathbf{a}), \mathrm{Mg}$ versus $\mathrm{Eu}(\mathbf{b}), \mathrm{Fe}$ versus $\mathrm{Co}(\mathbf{c})$ and $\mathrm{Nb}$ versus $\mathrm{Zr}(\mathbf{d})$ in soil samples from Lami, Leni and Pianogreca. Values of major elements are expressed in \% (w/w) and values of trace elements in mg/kg

samples, suggesting a higher bioavailability of REE in soil in this study area. The contrary was observed in Lami and Pianogreca, suggesting thus a lower bioavailability of REE in soil in comparison with Leni. These results suggest that the lower bioavailability of REE in Lami and Pianogreca may be due to the andesite-dacite parent material of these areas in comparison with the basaltic-andesite parent material of Leni soil. These differences may therefore be used to geochemically discriminate capers grown on substrates from different areas, tracing thus the geographical origin of products (Censi et al. 2014).
Chemical composition in caper samples

Major and trace elements concentrations in caper samples from the three studied areas in Lipari and Salina are listed in Table 6. Statistically significant differences $(p<0.05)$ were obtained for all major and trace elements except $\mathrm{Cu}$. For major elements, the highest concentration in all areas was that of $\mathrm{K}$, followed by $\mathrm{P}, \mathrm{Ca}, \mathrm{Mg}$ and $\mathrm{Na}$. For trace elements, the highest concentration was that of $\mathrm{Rb}$, followed by $\mathrm{Zn}$, $\mathrm{Fe}, \mathrm{Ti}, \mathrm{B}, \mathrm{Sr}, \mathrm{Mn}, \mathrm{Ba}, \mathrm{Al}$ and Mo: however, in Leni, the $\mathrm{Ba}$ concentration was higher than $\mathrm{Al}$ (Table 6). Correlations among major and trace elements in caper samples were also calculated for all study areas: all 
Table 6 Median concentrations of major and trace elements in caper samples of the three studied areas analysed by ICP-MS

\begin{tabular}{|c|c|c|c|c|}
\hline & Lami & Leni & Pianogreca & $p$ value \\
\hline $\mathrm{Ca}$ & $0.46 \pm 0.07$ & $0.66 \pm 0.12$ & $0.25 \pm 0.04$ & $* * *$ \\
\hline $\mathrm{K}$ & $3.35 \pm 0.22$ & $3.06 \pm 0.37$ & $2.62 \pm 0.23$ & $* * *$ \\
\hline $\mathrm{Mg}$ & $0.26 \pm 0.03$ & $0.29 \pm 0.02$ & $0.24 \pm 0.03$ & $* * *$ \\
\hline $\mathrm{P}$ & $0.35 \pm 0.02$ & $0.36 \pm 0.04$ & $0.46 \pm 0.04$ & $* * *$ \\
\hline $\mathrm{Al}$ & $3.96 \pm 0.68$ & $1.57 \pm 0.17$ & $3.73 \pm 0.14$ & $* * *$ \\
\hline B & $26.8 \pm 2.0$ & $31.2 \pm 5.4$ & $16.8 \pm 1.74$ & $* * *$ \\
\hline $\mathrm{Ba}$ & $1.15 \pm 0.13$ & $2.88 \pm 1.15$ & $2.16 \pm 0.39$ & $* * *$ \\
\hline $\mathrm{Cu}$ & $16.1 \pm 2.0$ & $16.4 \pm 3.1$ & $17.4 \pm 1.65$ & n.s \\
\hline $\mathrm{Fe}$ & $101 \pm 9.4$ & $78.3 \pm 5.4$ & $36.7 \pm 5.61$ & $* * *$ \\
\hline $\mathrm{Mn}$ & $14.6 \pm 3.0$ & $22.7 \pm 7.4$ & $7.68 \pm 0.68$ & $* * *$ \\
\hline $\mathrm{Li}$ & $5.60 \pm 0.06$ & $0.04 \pm 0.02$ & $0.03 \pm 0.01$ & $* * *$ \\
\hline $\mathrm{Na}$ & $107 \pm 38$ & $217 \pm 73$ & $106 \pm 8.1$ & $* *$ \\
\hline $\mathrm{Ni}$ & $1.33 \pm 0.32$ & $1.72 \pm 0.28$ & $0.84 \pm 0.09$ & $* * *$ \\
\hline $\mathrm{Rb}$ & $120 \pm 19$ & $53.0 \pm 13.2$ & $113 \pm 6.2$ & $* * *$ \\
\hline $\mathrm{Sr}$ & $18.7 \pm 3.1$ & $33.5 \pm 9.7$ & $16.4 \pm 3.6$ & $* * *$ \\
\hline $\mathrm{Ti}$ & $12.6 \pm 2.2$ & $13.7 \pm 4.1$ & $24.1 \pm 1.3$ & $* * *$ \\
\hline $\mathrm{Zn}$ & $67.4 \pm 11.7$ & $80.1 \pm 14.2$ & $46.4 \pm 3.6$ & $* * *$ \\
\hline $\mathrm{Cd}$ & $45.7 \pm 15.8$ & $73.4 \pm 23.3$ & $76.7 \pm 14.7$ & $* *$ \\
\hline $\mathrm{Ce}$ & $21.4 \pm 5.3$ & $15.8 \pm 3.20$ & $14.6 \pm 2.6$ & n.s \\
\hline Co & $143 \pm 34$ & $172 \pm 47$ & $23.4 \pm 7.27$ & $* * *$ \\
\hline $\mathrm{Cr}$ & $81.7 \pm 10.9$ & $215 \pm 65$ & $206 \pm 60$ & $* * *$ \\
\hline Dy & n.d & $0.79 \pm 0.41$ & $0.32 \pm 0.25$ & $* * *$ \\
\hline $\mathrm{Er}$ & $0.29 \pm 0.07$ & $0.28 \pm 0.23$ & $0.23 \pm 0.17$ & $*$ \\
\hline $\mathrm{Eu}$ & $0.31 \pm 0.19$ & $0.83 \pm 0.19$ & $0.63 \pm 0.16$ & $* * *$ \\
\hline $\mathrm{Gd}$ & $0.30 \pm 0.08$ & $1.71 \pm 0.63$ & $0.29 \pm 0.21$ & $* * *$ \\
\hline Ho & n.d & $0.28 \pm 0.15$ & n.d & n.s \\
\hline $\mathrm{La}$ & $5.29 \pm 0.63$ & $7.19 \pm 1.53$ & $5.69 \pm 1.95$ & $*$ \\
\hline Mo & $974 \pm 113$ & $980 \pm 159$ & $749 \pm 78$ & $* * *$ \\
\hline $\mathrm{Nb}$ & $69.7 \pm 28.3$ & $2.27 \pm 1.74$ & $2.91 \pm 1.92$ & $* * *$ \\
\hline $\mathrm{Nd}$ & $2.71 \pm 1.87$ & $4.91 \pm 1.54$ & $3.65 \pm 2.43$ & $*$ \\
\hline $\mathrm{Pb}$ & $30.4 \pm 10.5$ & $35.1 \pm 21.4$ & $18.1 \pm 8.8$ & $* *$ \\
\hline $\operatorname{Pr}$ & $1.48 \pm 0.26$ & $1.63 \pm 0.85$ & $1.69 \pm 0.28$ & n.s \\
\hline $\mathrm{Sm}$ & $0.28 \pm 0.11$ & $1.38 \pm 0.35$ & $0.56 \pm 0.16$ & $* * *$ \\
\hline $\mathrm{Tb}$ & $0.41 \pm 0.34$ & $0.30 \pm 0.08$ & $0.09 \pm 0.13$ & $* *$ \\
\hline Th & $0.33 \pm 0.22$ & $1.71 \pm 0.87$ & $2.43 \pm 0.94$ & $* * *$ \\
\hline $\mathrm{U}$ & $360 \pm 239$ & $17.0 \pm 25.7$ & $0.51 \pm 0.22$ & $* * *$ \\
\hline $\mathrm{V}$ & $162 \pm 50$ & $230 \pm 29$ & $79.0 \pm 10.1$ & $* * *$ \\
\hline Y & $0.29 \pm 0.02$ & $4.63 \pm 1.42$ & $3.20 \pm 2.19$ & $* * *$ \\
\hline $\mathrm{Yb}$ & $0.31 \pm 0.07$ & $0.30 \pm 0.19$ & $0.30 \pm 0.16$ & n.s \\
\hline
\end{tabular}

Table 6 continued

\begin{tabular}{lllll}
\hline & Lami & Leni & Pianogreca & $p$ value \\
\hline $\mathrm{Zr}$ & $5.51 \pm 2.61$ & $73.8 \pm 8.6$ & $18.6 \pm 3.82$ & $* * *$ \\
\hline
\end{tabular}

A nonparametric multiple test (Test di Kruskal-Wallis) was applied. Major elements from $\mathrm{Ca}$ to $\mathrm{P}$ are expressed in \% (w/ $\mathrm{w})$, and trace elements from $\mathrm{Al}$ to $\mathrm{Zn}$ are expressed in $\mathrm{mg} / \mathrm{kg}$ and from $\mathrm{Cd}$ to $\mathrm{Zr}$ are expressed in $\mu \mathrm{g} / \mathrm{kg}$. Experimental values correspond to the median \pm standard deviation (SD)

$n s$ not significant

$p$ values $*<0.05 ; * *<0.01 ; * * *<0.001$

elements in caper samples showed significant positive and negative correlations $(p<0.05)$, except $\mathrm{Nb}$ in Lami and $\mathrm{Nb}$ and $\mathrm{U}$ in Pianogreca (Appendix Table A.2 in Supplementary material). Comparing these data, a significant positive correlation of $\mathrm{K}$ versus $\mathrm{Mg}$ was detected in Pianogreca, but no correlations between these elements appeared in Lami and Leni: these data suggest a different mobility of these elements in the different areas.

The content values of major and trace elements in caper samples shown in Table 6 were plotted in Fig. 5 together with linear regression values. A positive correlation was detected for Ca versus $\mathrm{Mg}$ (Fig. 5a), in accordance with high contents of $\mathrm{Ca}$ and $\mathrm{Mg}$ and higher bioavailability of $\mathrm{Ca}$ and $\mathrm{Mg}$ in all study areas (Morard et al. 1996; Navarro et al. 2000; Kötschau et al. 2014), related to the abundance of primary minerals such as augite, hornblende and the feldspar plagioclase (Troeh and Thompson 1993; Barker and Pilbeam 2007; Kabata-Pendias 2011).

A well-defined positive linear regression of $\mathrm{Sr}$ versus Ba (Fig. 5b) was observed in all the investigated areas. Previous studies supported the close relationship and the synergy between $\mathrm{Sr}$ and $\mathrm{Ba}$, according to the plant metabolic requirements (Kabata-Pendias 2011). Concerning $\mathrm{Rb}$ versus $\mathrm{Fe}$ (Fig. 5c), no significant correlation was detected, but these two elements clearly showed different rates for the three studied areas, suggesting a different bioaccumulation of $\mathrm{Rb}$ and $\mathrm{Fe}$ with respect to geographical origin.

No significant correlation was also observed for $\mathrm{Ca}$ versus V (Fig. 5d) but some separation of rates according to geographical origin could be detected: this suggests a different uptake and accumulation of $\mathrm{V}$ in caper plants according to the concentration of this element in the investigated areas. 
Fig. 4 Concentrations of rare earth elements determined by ICP-MS expressed in $\mathrm{mg} / \mathrm{kg}$ in soil samples and $\mu \mathrm{g} / \mathrm{g}$ in caper samples and normalized by the chondrite values, in soil (a) and caper (b) samples from Lami, Leni and Pianogreca. The concentrations of $\mathrm{Tm}$ and $\mathrm{Lu}$ in caper samples were below the detection limit of ICPMS

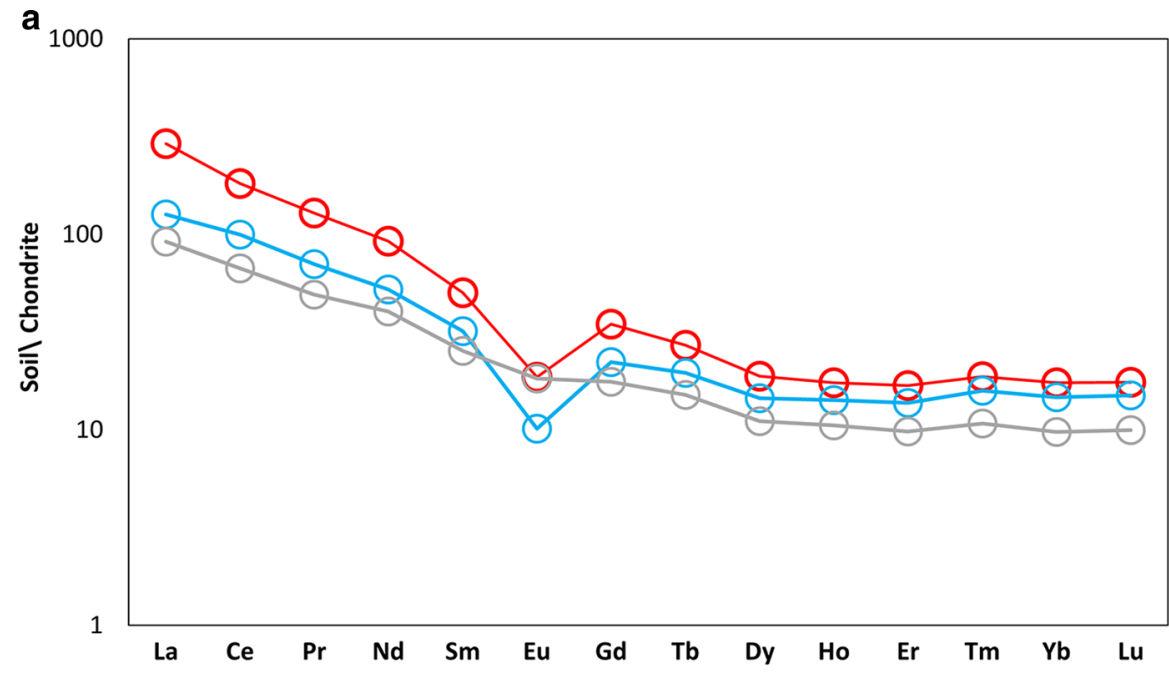

b

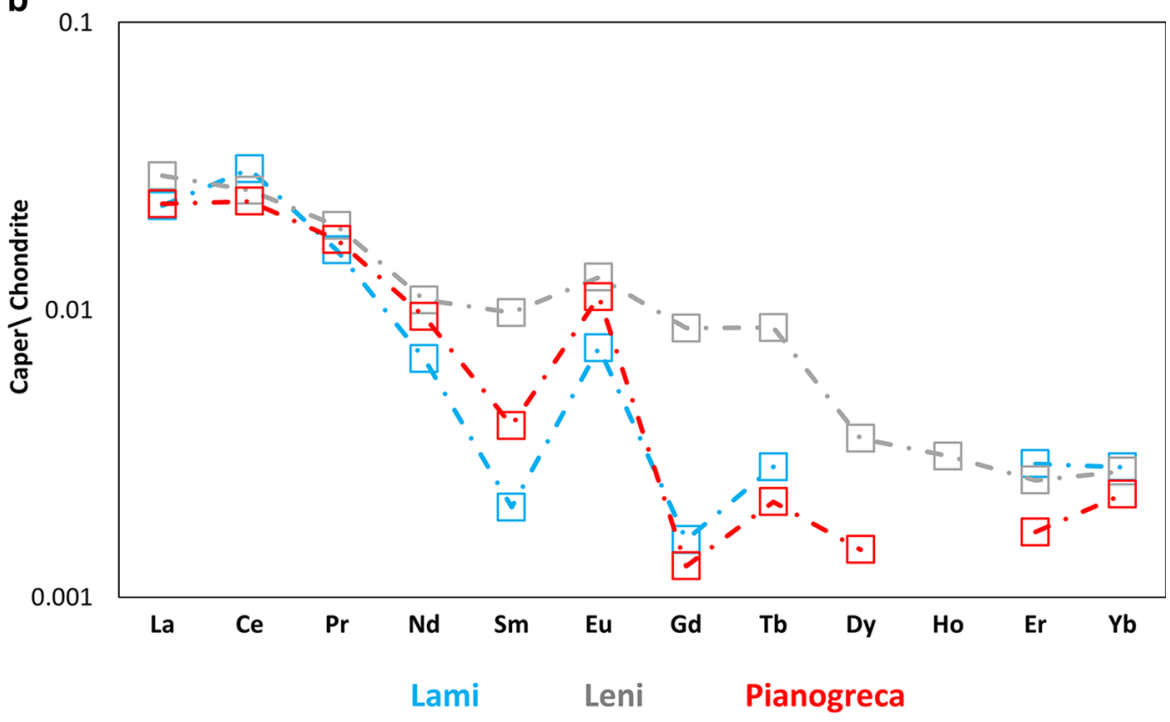

Well-defined positive correlations were observed for $\mathrm{V}$ versus $\mathrm{Ni}$ in Lami (Fig. 5e), Ni versus $\mathrm{Zn}$ in all areas (Fig. 5f), and $\mathrm{Zn}$ versus $\mathrm{B}$ (Fig. 5g) and $\mathrm{Ti}$ versus $\mathrm{P}$ (Fig. 5h) in Lami and Pianogreca. Concerning the correlations of these trace elements, the first one supports the data obtained for $\mathrm{Ca}$ versus $\mathrm{V}$ and the second one suggests that the absorption of $\mathrm{Ni}$ and its translocation in caper plants are favoured by $\mathrm{Zn}$ (Kaplan et al. 1990; Kabata-Pendias 2011). The positive correlation between $\mathrm{Zn}$ and B suggests that uptake of $B$ by the plant may increase in the presence of $\mathrm{Zn}$, because $\mathrm{Zn}$ exerts a partial protective effect against toxic levels of B in rooting zones (KabataPendias 2011).
The interactions between $\mathrm{P}$ and Ti are complex: in plants, an interference of $\mathrm{P}$ ions with Ti mobility has been previously reported, probably similar to $\mathrm{OH}$ groups reactions (Kabata-Pendias 2011), but no interference between these two trace elements was detected in the areas of the present study.

Again, the differences in correlations of major and trace elements shown in Fig. 5 appear closely related to soil type and geographical origin, suggesting thus that these parameters could be useful as geographical origin markers of Italian caper. 

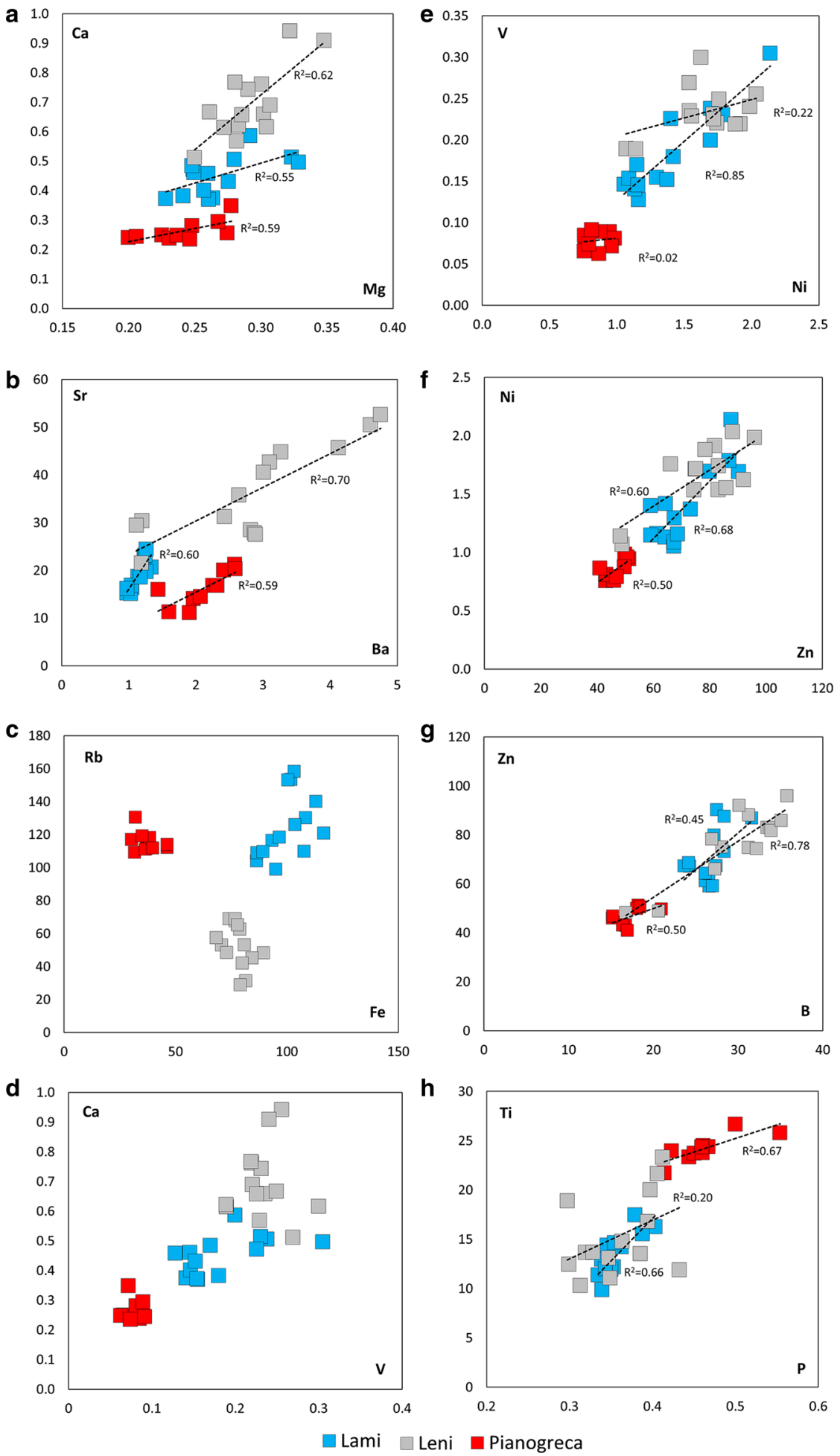

Fig. 5 Bivariate plots of major and trace elements of $\mathrm{Mg}$ versus $\mathrm{Ca}(\mathbf{a}), \mathrm{Ba}$ versus $\mathrm{Sr}(\mathbf{b}), \mathrm{Fe}$ versus $\mathrm{Rb}$ (c) $\mathrm{V}$ versus $\mathrm{Ca}(\mathbf{d}), \mathrm{Ni}$ versus $\mathrm{V}$ (e) $\mathrm{Zn}$ versus $\mathrm{Ni}(\mathbf{f}), \mathrm{B}$ versus $\mathrm{Zn}$ (g) and $\mathrm{P}$ versus Ti (h) in caper samples from the three studied areas. Values of major elements are expressed in $\%(\mathrm{w} / \mathrm{w})$ and values of trace elements in $\mathrm{mg} / \mathrm{kg}$. The coefficient of determination $\left(R^{2}\right)$ is indicated 
Correlations among elements in soil and caper samples

The results concerning the different contents of elements in soil and caper samples presented in Tables 5 and 6 were used to assess the correlations between these elements and identify possible geochemical features of the soil associated with capers. The contents of elements in soil were plotted against those in capers, calculating the linear regression values. Only four elements ( $\mathrm{Co}, \mathrm{Fe}, \mathrm{Mg}$ and $\mathrm{Rb}$ ) showed a significant correlation $\left(R^{2}>0.60\right)$ with an internal and external $95 \%$ confidence interval (Fig. 6). A significant positive correlation was found for $\mathrm{Co}$ and $\mathrm{Mg}$ in Lami (Fig. 6a, d), for $\mathrm{Co}$ and $\mathrm{Fe}$ in Leni (Fig. 6b, e) and for Mg and Rb in Pianogreca (Fig. 6c, f).

The soil-caper positive correlation for Co detected in Lami and Leni may be related to the interchangeability of this element with $\mathrm{Mg}, \mathrm{Fe}$ and $\mathrm{Mn}$, previously documented in plant tissues (Kabata-Pendias 2011). Concerning $\mathrm{Mg}$, its capacity to be easily assimilated by plants from the soil and therefore its correlation with the soil content have been widely described (Barker and Pilbeam 2007; Kabata-Pendias 2011; Kötschau et al. 2014). This element is known to be present in caper and caperberries in significant contents (Özcan, 1999). In this study, the content of $\mathrm{Mg}$ appears able to discriminate capers from two different localities of the same island, Lami and Pianogreca.

A well-defined positive linear regression for $\mathrm{Fe}$ could be due to the high absorption capacity by the plants. The uptake of $\mathrm{Fe}$ in plants and its transport among plant tissues are related to the chemical species of $\mathrm{Fe}$ that are $\mathrm{Fe}^{2+}, \mathrm{Fe}^{3+}$ and $\mathrm{Fe}$ chelates. The plant root may introduce $\mathrm{Fe}^{3+}$ and reduce it to $\mathrm{Fe}^{2+}$, the species which is most readily transported in plant organs (Kabata-Pendias 2011).

The soil-caper positive correlation detected for $\mathrm{Rb}$ in Pianogreca could be explained by the higher content of this element in volcanic sediments rich in feldspat minerals (Fig. 6f). The Rb values could also be related to the interchangeability of this element with $\mathrm{K}$ (Kabata-Pendias 2011).

The results of soil-caper correlations among the major and trace elements show that $\mathrm{Co}, \mathrm{Mg}, \mathrm{Fe}$ and $\mathrm{Rb}$ are relevant to connect the caper plant to the geochemical location of the soil, discriminating among the areas of caper cultivation in Lami, Leni and Pianogreca, identifying thus its territoriality.

Multivariate analysis

Principal component analysis (PCA) was applied to soil and caper data (Tables 5,6) to evaluate geochemical differences derived from geographical origin (Fig. 7). In soil samples, the model generated by PCA analysis explained $83.4 \%$ of total variance. The correlation-loading plot of soil samples (Fig. 7a) showed that the variables $\mathrm{B}, \mathrm{Ca}, \mathrm{Cd}, \mathrm{Co}, \mathrm{Fe}, \mathrm{K}, \mathrm{Li}$, $\mathrm{Mg}, \mathrm{Mn}, \mathrm{Mo}, \mathrm{Nb}, \mathrm{Ni}, \mathrm{Rb}$, Th, V, Y and Zr, but not $\mathrm{Eu}$, were strongly correlated with F1, explaining $63.3 \%$ of variance. The remaining variables $(\mathrm{Ba}, \mathrm{Eu}$ and $\mathrm{P}$ ) were strongly correlated with $\mathrm{F} 2$, explaining $20.0 \%$ of variance. In detail, elements such as $\mathrm{B}, \mathrm{K}, \mathrm{Li}, \mathrm{Mo}, \mathrm{Na}$, $\mathrm{Nb}, \mathrm{Rb}$ and $\mathrm{Zr}$ were important in discriminating Lami, $\mathrm{Al}, \mathrm{Ca}, \mathrm{Co}, \mathrm{Mg}, \mathrm{Mn}, \mathrm{Ni}, \mathrm{Ti}$ and $\mathrm{V}$ were important in discriminating Leni and $\mathrm{Cd}$, REE and $\mathrm{Y}$ in discriminating Pianogreca.

When the PCA analysis was applied to caper data, the model generated by the analysis explained $56.6 \%$ of total variance. The correlation-loading plot of caper samples (Fig. 7b) showed that variables including Al, $\mathrm{Ca}, \mathrm{Gd}, \mathrm{Mn}, \mathrm{Na}, \mathrm{Ni}, \mathrm{Rb}, \mathrm{Sm}, \mathrm{V}$ and $\mathrm{Zr}$ were strongly correlated with F1, explaining $32.3 \%$ of variance. The remaining variables, $\mathrm{Cr}, \mathrm{Fe}, \mathrm{K}, \mathrm{Li}, \mathrm{Nb}, \mathrm{Ti}$ and $\mathrm{Th}$, were strongly correlated with F2, explaining $24.3 \%$ of variance. Elements such as $\mathrm{Al}, \mathrm{Fe}, \mathrm{K}, \mathrm{Li}$ and $\mathrm{Nb}$ were thus useful for the discrimination of samples from Lami, while $\mathrm{Ca}, \mathrm{Dy}, \mathrm{Gd}, \mathrm{Na}, \mathrm{Sm}, \mathrm{Sr}$ and $\mathrm{Zr}$ were important in discriminating samples from Leni and $\mathrm{P}$ and Ti from Pianogreca.

The PCA analysis was also applied to jointly evaluate the soil and caper data in order to identify suitable geochemical markers of geographical origin. The model generated by PCA analysis explained $92.9 \%$ of total variance. The correlation-loading plot of joint data (Fig. 7c) showed that variables $\mathrm{Al}, \mathrm{Ba}$, $\mathrm{Ca}, \mathrm{Cd}, \mathrm{Co}, \mathrm{Cr}, \mathrm{Fe}, \mathrm{Li}, \mathrm{Mg}, \mathrm{Mo}, \mathrm{Mn}, \mathrm{Na}, \mathrm{Ni}, \mathrm{P}, \mathrm{Pb}, \mathrm{Sr}$, $\mathrm{Th}, \mathrm{Ti}, \mathrm{V}, \mathrm{Y}$ and $\mathrm{Zr}$ were strongly correlated with F1, explaining $77.0 \%$ of variance. The elements $\mathrm{K}, \mathrm{Rb}$ and Zn were strongly correlated with F2, explaining $15.9 \%$ of variance.

Overall, the PCA analysis shown in Fig. 7 supports the hypothesis that an excellent discrimination of geographical origin is possible for capers grown in Lami, Leni and Pianogreca. 

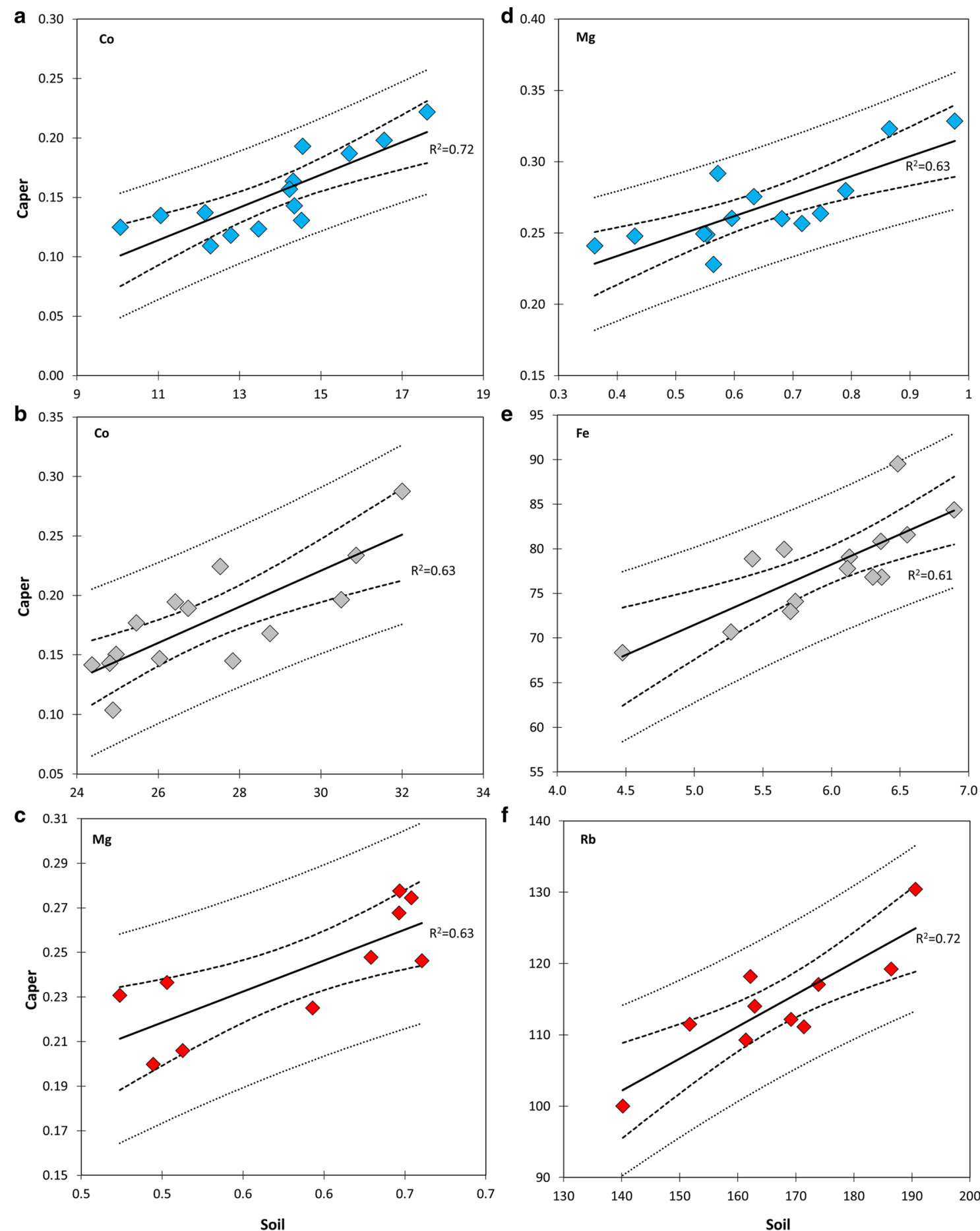

— L.Regression $\quad$-..- Internal Confidence $\quad$....... External Confidence

\section{Lami $\diamond$ Leni $\diamond$ Pianogreca}

Fig. 6 Linear regression values (continuous line) of concentrations of $\mathrm{Co}(\mathbf{a}, \mathbf{b}), \mathrm{Mg}(\mathbf{c}, \mathbf{d}), \mathrm{Fe}(\mathbf{e})$ and $\mathrm{Rb}(\mathbf{f})$ in soil versus caper samples, showing a significant correlation $\left(R^{2}>0.60\right)$ with an internal (dashed line) and external (dotted line) 95\% confidence interval. The value of $\mathrm{Mg}$ is expressed in $\%(\mathrm{w} / \mathrm{w})$, and the values of $\mathrm{Co}, \mathrm{Fe}$ and $\mathrm{Rb}$ are expressed in $\mathrm{mg} / \mathrm{kg}$ 

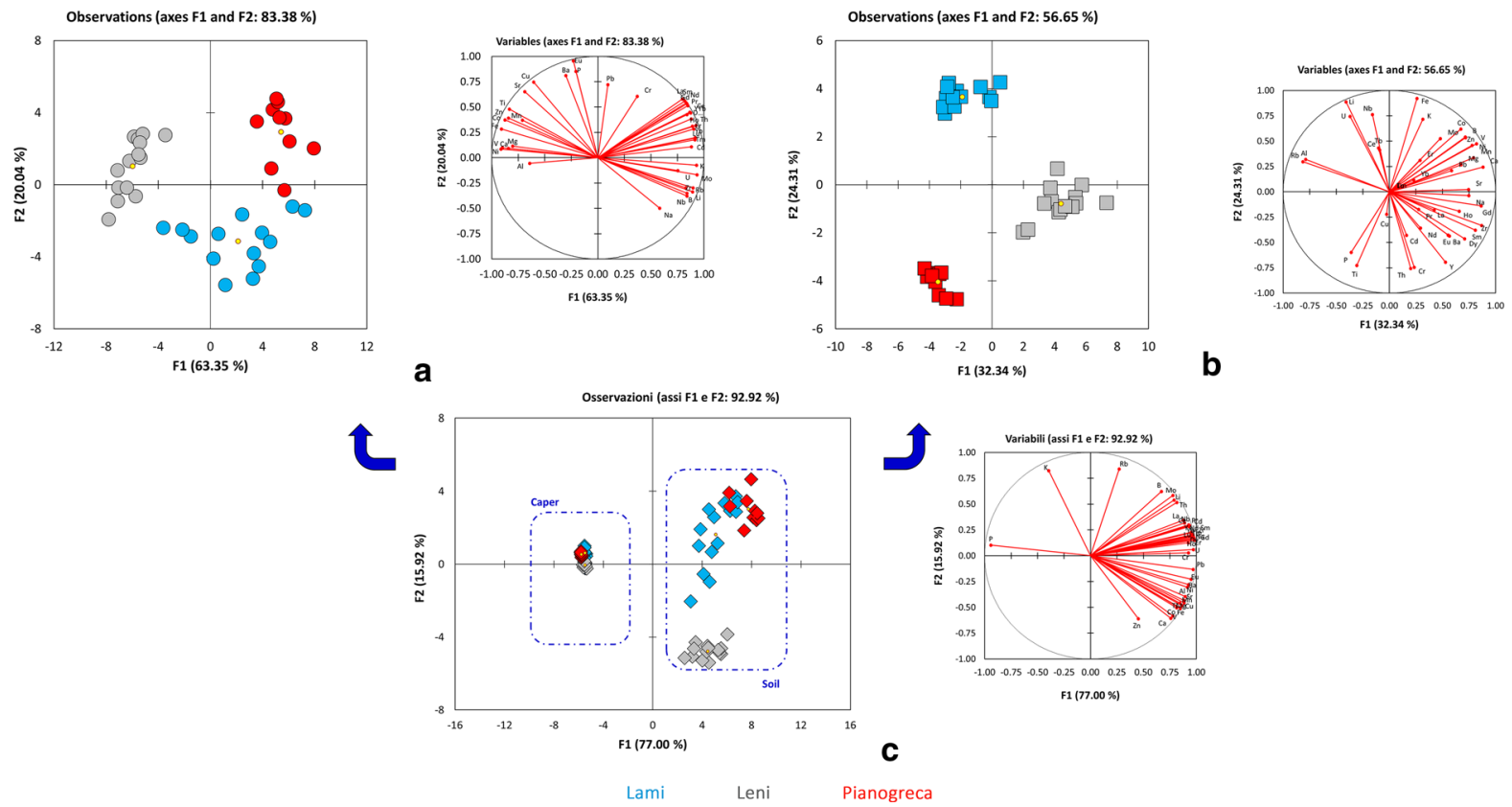

Fig. 7 Principal component analysis (PCA) plot of the values of elemental concentrations in soil (a) caper (b) and soil-caper (c) of Lami, Leni and Pianogreca, shown in Tables 5 and 6. The

\section{Conclusions}

Major and trace elements in soil and caper samples from two locations in Lipari Island, Lami and Pianogreca, and one in Salina Island, Leni, were evaluated as possible geographical markers for the territoriality of products "Made in Italy". The analyses of soil samples by XRF and ICP-MS were able to geochemically characterize and discriminate the three investigated areas. In caper samples, the analysis by ICP-MS confirmed a different accumulation of major and trace elements in the three locations. The $\mathrm{Eu}$ anomaly detected by ICP-MS in soil samples allowed to identify the petrogenetic processes occurring in Lipari Island in comparison with those occurring in Salina, while $\mathrm{Eu}, \mathrm{Gd}$ and $\mathrm{Sm}$ anomalies detected in caper samples reflected those of the respective growth areas, supporting the hypothesis that these parameters could be used for tracing the origin of products.

The results obtained by ICP-MS show that the elements strongly correlated from a geochemical point of view in soil and caper samples are $\mathrm{Co}, \mathrm{Fe}, \mathrm{Mg}$ and $\mathrm{Rb}$. factor loading plot is shown on the right side: F1, first discriminant function; F2, second discriminant function

The PCA analysis allowed to discriminate soil and caper samples from Lami, Leni and Pianogreca according to their geographical origin. The elements useful as geochemical markers were $\mathrm{Al}, \mathrm{B}, \mathrm{Ca}, \mathrm{Co}, \mathrm{Fe}$, $\mathrm{Li}, \mathrm{Mg}, \mathrm{Mn}, \mathrm{Nb}, \mathrm{Ni}, \mathrm{Rb}, \mathrm{Sr}, \mathrm{Ti}, \mathrm{V}$ and $\mathrm{Zr}$, but among them, $\mathrm{Co}, \mathrm{Fe}, \mathrm{Mg}$ and $\mathrm{Rb}$ were able to establish a reliable correlation between geolithological features of soil and the chemical composition of capers.

Overall, the results of the present study confirm that some major and trace elements could be used as geochemical markers of capers according to the geological areas. These elements therefore could be useful to establish geochemical caper fingerprints (GCF) for testing the origin of this product and create a protected designation of origin (PDO) label, in order to protect the "Made in Italy" trademarks against the falsifications.

Acknowledgements The authors owe thanks to Renzo Tassinari for technical advice and experimental support, and Nunziata Picone, Guglielmo Sardella, Bartolo Cambria and Salvatore D'Amico for their support in the sampling campaign. The authors also wish to thank Dr. Milvia Chicca for useful suggestions in the manuscript. 


\section{References}

Aceto, M., Robotti, E., Oddone, M., Baldizzone, M., Bonifacino, G., Bezzo, G., et al. (2013). A traceability study on the Moscato wine chain. Food Chemistry, 138, 1914-1922.

Adamo, P., Zampella, M., Quétel, C. R., Aversano, R., Dal Piaz, F., De Tommasi, N., et al. (2012). Biological and geochemical markers of the geographical origin and genetic identity of potatoes. Journal Geochemical Exploration, 121, 62-68.

Aide, M. T., \& Aide, C. (2012). Rare earth elements: Their importance in understanding soil genesis. International Scholarly Research Notices, 2012, 1-11.

Almeida, M., \& Vasconcelos, M. T. (2003). Multielement composition of wines and their precursors including provenance soil and their potentialities as fingerprints of wine origin. Journal of Agricultural and Food Chemistry, $51,4788-4798$.

Ariyama, K., Aoyama, Y., Mochizuki, A., Homura, Y., Kadokura, M., \& Yasui, A. (2007). Determination of the geographic origin of onions between three main production areas in Japan and other countries by mineral composition. Journal of Agricultural and Food Chemistry, 55, 347-354.

Bandoniene, D., Zettl, D., Meisel, T., \& Maneiko, M. (2013). Suitability of elemental fingerprinting for assessing the geographic origin of pumpkin (Cucurbita pepo var. styriaca) seed oil. Food Chemistry, 136, 1533-1542.

Barbera, G., \& Di Lorenzo, R. (1982). La coltura specializzata del cappero nell'isola di Pantelleria. L'informatore Agrario, 38, 2113-2117.

Barker, A. L., \& Pilbeam, D. J. (2007). Handbook of plant nutrition (1st ed.). Boca Raton, FL: Taylor \& Francis Group, LLC.

Bigazzi, G., Coltelli, M., \& Norelli, P. (2003). Nuove età delle ossidiane di Lipari determinate con il metodo delle tracce di fissione. Geoitalia, Bellaria, 48, 444-446.

Bong, Y. S., Song, B. Y., Gautam, M. K., Jang, C. S., An, H. J., \& Lee, K. S. (2013). Discrimination of the geographic origin of cabbages. Food Control, 30, 626-630.

Brioschi, L., Steinmann, M., Lucot, E., Pierret, M. C., Stille, P., Prunier, J., et al. (2013). Transfer of rare earth elements (REE) from natural soil to plant systems: Implications for the environmental availability of anthropogenic REE. Plant and Soil, 366, 143-163.

Calanchi, N., Peccerillo, A., Tranne, C. A., Lucchini, F., Rossi, P. L., Kempton, L., et al. (2002). Petrology and geochemistry of volcanic rocks from the island of Panarea: Implications for mantle evolution beneath the Aeolian island arc (southern Tyrrhenian sea). Journal of Volcanology and Geothermal Research, 115, 367-395.

Camargo, A. B., Resnizky, S., Marchevsky, E. J., \& Luco, J. M. (2010). Use of the Argentinean garlic (Allium sativum L.) germplasm mineral profile for determining geographic origin. Journal of Food Composition and Analysis, 23, 586-591.

Censi, P., Saiano, F., Pisciotta, A., \& Tuzzolino, N. (2014). Geochemical behaviour of rare earths in Vitis vinifera grafted onto different rootstocks and growing on several soils. Science of the Total Environment, 474, 597-608.
Cicchino, A. M. P., Zanella, E., De Astis, G., Lanza, R., Lucchi, F., Tranne, C. A., et al. (2011). Rock magnetism and compositional investigation of Brown Tuffs deposits at Lipari and Vulcano (Aeolian Islands-Italy). Journal of Volcanology and Geothermal Research, 208, 23-38.

D'Antone, C., Punturo, R., \& Vaccaro, C. (2017). Rare earth elements distribution in grapevine varieties grown on volcanic soils: An example from Mount Etna (Sicily, Italy). Environmental Monitoring and Assessment. https://doi. org/10.1007/s10661-017-5878-6.

De la Guardia, M., \& Gonzálvez, A. (2013). Food protected designation of origin: Methodologies and applications (1st ed.). Amsterdam: Elsevier.

Di Giacomo, F., Del Signore, A., \& Giacco, M. (2007). Determining the geographic origin of potatoes using mineral and trace element content. Journal of Agricultural and Food Chemistry, 55, 860-866.

Ewart, A. (1982). The mineralogy and petrology of tertiaryrecent orogenic volcanic rocks: With special reference to the andesitic-basaltic compositional range. In R. S. Thorn (Ed.), Andesites: Orogenic andesites and related rocks (pp. 25-95). New York, NY: Wiley.

Fabiani, M. P., Arrúa, R. C., Vázquez, F., Diaz, M. P., Baron, M. V., \& Wunderlin, D. A. (2010). Evaluation of elemental profile coupled to chemometrics to assess the geographical origin of Argentinean wines. Food Chemistry, 119, 372-379.

Forni, F., Lucchi, F., Peccerillo, A., Tranne, C. A., Rossi, P. L., \& Frezzotti, M. L. (2013). Stratigraphy and geological evolution of Lipari volcanic complex (central Aeolian archipelago). In F. Lucchi, A. Peccerillo, J. Keller, C. A. Tranne, \& P. L. Rossi (Eds.), The Aeolian islands volcanoes (pp. 213-279). London: Geological Society Memoirs.

Furia, E., Naccarato, A., Sindona, G., Stabile, G., \& Tagarelli, A. (2011). Multielement fingerprinting as a tool in origin authentication of PGI food products: Tropea red onion. Journal of Agricultural and Food Chemistry, 59, 8450-8457.

Gonzálvez, A., Llorens, A., Cervera, M. L., Armenta, S., \& De la Guardia, M. (2000). Elemental fingerprint of wines from the protected designation of origin Valencia. Food Chemistry, 112, 26-34.

Inocencio, C., Alcaraz, F., Calderón, F., Obón, C., \& Rivera, D. (2002). The use of floral characters in Capparis sect. Capparis to determine the botanical and geographical origin of capers. European Food Research and Technology, 214, 335-339.

Inocencio, C., Cowan, R. S., Alcaraz, F., Rivera, D., \& Fay, M. F. (2005). AFLP fingerprinting in Capparis subgenus Capparis related to the commercial sources of capers. Genetic Resources and Crop Evolution, 52, 44-137.

Kabata-Pendias, A. (2011). Trace elements in soils and plants (4th ed.). Boca Raton, FL: CRC Press.

Kaplan, D. I., Adriano, D. C., Carlson, C. L., \& Sajwan, K. S. (1990). Vanadium: Toxicity and accumulation by beans. Water, Air, and Soil Pollution, 49, 81-91.

Kötschau, A., Büchel, G., Einax, J. W., Meißner, R., von Tümpling, W., \& Merten, D. (2014). Element pattern recognition and classification in sunflowers (Helianthus 
annuиs) grown on contaminated and non-contaminated soil. Microchemical Journal, 114, 164-174.

Kruk, J., Burda, K., Jemiola-Rzeminska, M., \& Strzalka, K. (2003). The $33 \mathrm{kDa}$ protein of photosystem II is a low affinity calcium- and lanthanide-binding protein. Biochemical Journal, 42, 14862-14867.

Lanzo, G., Basile, S., Brai, M., \& Rizzo, S. (2010). Volcanic products of Lipari (Aeolian Islands, Italy): Multivariate analysis of petrographic and radiometric data. Radiation Measurements, 45, 816-822.

Le Bas, M. J., Le Maitre, R. W., Streckeisen, A., \& Zanettin, B. (1986). A chemical classification of volcanic rocks based on the total alkali-silica diagram. Journal Petrology, 27, $745-750$.

Liu, H. C., You, C. F., Chen, C. Y., Liu, Y. C., \& Chung, M. T. (2014). Geographic determination of coffee beans using multi-element analysis and isotope ratios of boron and strontium. Food Chemistry, 142, 439-445.

Lo Feudo, G., Naccarato, A., Sindona, G., \& Tagarelli, A. (2010). Investigating the origin of tomatoes and triple concentrated tomato pastes through multielement determination by inductively coupled plasma mass spectrometry and statistical analysis. Journal of Agricultural and Food Chemistry, 58, 3801-3807.

Longobardi, F., Casiello, G., Cortese, M., Perini, M., Camin, F., Catucci, L., et al. (2015). Discrimination of geographical origin of lentils (Lens culinaris Medik.) using isotope ratio mass spectrometry combined with chemometrics. Food Chemistry, 188, 343-349.

Lucchi, F., Gertisser, R., Keller, J., Forni, F., De Astis, G., \& Tranne, C. A. (2013a). Eruptive history and magmatic evolution of the island of Salina (central Aeolian archipelago). In F. Lucchi, A. Peccerillo, J. Keller, C. A. Tranne, \& P. L. Rossi (Eds.), The Aeolian islands volcanoes (pp. 155-211). London: Geological Society Memoirs.

Lucchi, F., Peccerillo, A., Keller, J., Tranne, C. A., \& Rossi, P. L. (2013b). The Aeolian islands volcanoes (1st ed.). London: Geological Society Memoir.

Ma, G., Zhang, Y., Zhang, J., Wang, G., Chen, L., Zhang, M., et al. (2016). Determining the geographical origin of Chinese green tea by linear discriminant analysis of trace metals and rare earth elements: Taking Dongting Biluochun as an example. Food Control, 59, 714-720.

Mantrov, V. (2014). EU Law on indications of geographical origin theory and practice. Berlin: Springer.

McDonough, W. F., \& Sun, S. S. (1995). Composition of earth. Chemical Geology, 120, 223-253.

Mercurio, M., Grilli, E., Odierna, P., Morra, V., Prohaska, T., Coppola, E., et al. (2014). A 'Geo-Pedo-Fingerprint' (GPF) as a tracer to detect univocal parent material-to-wine production chain in high quality vineyard districts, Campi Flegrei (Southern Italy). Geoderma, 231, 64-78.

Merschel, G., Bau, M., Baldewein, L., Dantas, E. L., Walde, D., \& Bühn, B. (2015). Tracing and tracking wastewaterderived substances in freshwater lakes and reservoirs: Anthropogenic gadolinium and geogenic REEs in Lake Paranoà, Brasilia. Comptes Rendus Geoscience, 347, 284-293.

Morard, P., Pujos, A., Bernadac, A., \& Bertoni, G. (1996). Effect of temporary calcium deficiency on tomato growth and mineral nutrition. Journal of Plant Nutrition, 19, 115-127.
Navarro, J. M., Matinez, V., Cerda, A., \& Botella, M. A. (2000). Effect of salinity $\times$ calcium interaction on cation balance in melon plants grown under two regimes of orthophosphate. Journal of Plant Nutrition, 21, 991-1006.

Nikkarinen, M., \& Mertanen, E. (2004). Impact of geological origin on trace element composition of edible mushrooms. Journal of Food Composition and Analysis, 17, 301-310.

Özcan, M. (1999). Pickling and storage of caperberries (Capparis spp.). European Food Research and Technology, 208, 379-382.

Pepi, S., Grisenti, P., Sansone, L., Chicca, M., \& Vaccaro, C. (2017a). Chemical elements as fingerprints of geographical origin in cultivars of Vitis vinifera L. raised on the same SO4 rootstock. Environmental Science and Pollution Research. https://doi.org/10.1007/s11356-017-0443-y.

Pepi, S., Sansone, L., Chicca, M., Marrocchino, E., \& Vaccaro, C. (2016). Distribution of rare earth elements in soil and grape berries of Vitis vinifera cv. "Glera". Environmental Monitoring and Assessment, 188, 477.

Pepi, S., Sansone, L., Chicca, M., \& Vaccaro, C. (2017b). Relationship among geochemical elements in soil and grapes as terroir fingerprintings in Vitis vinifera $\mathrm{L}$. cv. "Glera". Chemie Der Erde-Geochemistry, 77, 121-130.

Pepi, S., \& Vaccaro, C. (2017). Geochemical fingerprints of "Prosecco" wine based on major and trace elements. Environmental Geochemistry and Health. https://doi.org/10. 1007/s10653-017-0029-0.

Pii, Y., Zamboni, A., Dal Santo, S., Pezzotti, M., Varanini, Z., \& Pandolfini, T. (2017). Prospect on ionomic signatures for the classification of grapevine berries according to their geographical origin. Frontiers and Plant Science, 8, 1-7.

Protano, G., \& Rossi, S. (2014). Relationship between soil geochemistry and grape composition in Tuscany (Italy). Journal of Soil Science and Plant Nutrition, 177, 500-508.

Rencher, A. C. (2002). Methods of multivariate analysis (2nd ed.). New York: Wiley.

Rivera, D., Inocencio, C., Obón, C., \& Alcaraz, F. (2003). Review of food and medicinal uses of Capparis L. subgenus Capparis (Capparidaceae). Economic Botany, 57, 34-515.

Sozzi, G. O. (2001). Caper bush: Botany and horticulture. Horticultural Reviews, 27, 88-125.

Sozzi, G. O., Peter, K. V., Nirmal Babu, K., \& Divakaran, M. (2012). Capers and caperberries. In K. V. Peter (Ed.), Handbook of herbs and spices. Philadelphia: Woodhead Publishing Limited.

Swoboda, S., Brunner, M., Boulyga, S. F., Galler, P., Horacek, M., \& Prohaska, T. (2008). Identification of Marchfeld asparagus using $\mathrm{Sr}$ isotope ratio measurements by $\mathrm{MC}$ ICP-MS. Analytical and Bioanalytical Chemistry, 390, 487-494.

Thiel, G., Geisler, G., Blechschmidt, I., \& Danzer, K. (2004). Determination of trace elements in wines and classification according to their provenance. Analytical and Bioanalytical Chemistry, 378, 1630-1636.

Troeh, F. R., \& Thompson, L. M. (1993). Soils and soil fertility (6th ed.). New York: Oxford University Press.

Van Leeuwen, C., \& Seguin, G. (2006). The concept of terroir in viticulture. Journal of Wine Research, 17, 1-10.

Versari, A., Laurie, F. V., Ricci, A., Laghi, L., \& Parpinello, G. P. (2014). Progress in authentication, typification and 
traceability of grapes and wines by chemometric approaches. Food Research International, 60, 2-18.

Wilson, J. E. (1998). Terroir: The role of geology, climate, and culture in the making of French Wines (Wine Wheels). Hardcover.

Zeng, F., Tian, H., Wang, Z., An, Y., Gao, F., Zhang, L., et al. (2003). Effect of rare element europium on amaranthin synthesis in Amarathus caudatus seedlings. Biological Trace Element Research, 93, 271-282.

Zhao, H., Guo, B., Wei, Y., Zhang, B., Sun, S., Zhang, L., et al. (2011). Determining the geographic origin of wheat using multielement analysis and multivariate statistics. Journal of Agricultural and Food Chemistry, 59, 4397-4402. 